\title{
Beneficial Plant-Associated Microorganisms From Semiarid Regions and Seasonally Dry Environments: A Review
}

\begin{abstract}
Maria Leticia Bonatelli ${ }^{1 * \dagger}$, Gileno Vieira Lacerda-Júnior ${ }^{2 * t}$, Fábio Bueno dos Reis Junior ${ }^{3}$, Paulo Ivan Fernandes-Júnior ${ }^{4}$, Itamar Soares Melo ${ }^{2}$ and Maria Carolina Quecine ${ }^{1}$

'Department of Genetics, Luiz de Queiroz College of Agriculture, University of São Paulo, Piracicaba, Brazil, ${ }^{2}$ Brazilian Agricultural Research Corporation, Embrapa Meio Ambiente, Jaguariúna, Brazil, ${ }^{3}$ Brazilian Agricultural Research Corporation, Embrapa Cerrados, Planaltina, Brazil, ${ }^{4}$ Brazilian Agricultural Research Corporation, Embrapa Semiárido, Petrolina, Brazil
\end{abstract}

OPEN ACCESS

Edited by: Manuel Delgado Baquerizo, University of Alicante, Spain

Reviewed by:

Bobbi Lynne Helgason, University of Saskatchewan, Canada Emilio Rodriguez-caballero, University of Almería, Spain

*Correspondence:

Maria Leticia Bonatelli mlbonatelli@usp.br

Gileno Vieira Lacerda-Júnio gilenolacerdajr@gmail.com

${ }^{\dagger}$ These authors have contributed equally to this work and share first authorship

Specialty section: This article was submitted to Terrestrial Microbiology, a section of the journal

Frontiers in Microbiology

Received: 17 April 2020 Accepted: 03 December 2020 Published: 15 January 2021

Citation:

Bonatelli ML, Lacerda-Júnior GV, dos Reis Junior FB, Fernandes-Júnior PI, Melo IS and Quecine MC (2021) Beneficial Plant-Associated Microorganisms From Semiarid Regions and Seasonally Dry Environments:

A Review.

Front. Microbiol. 11:553223. doi: 10.3389/fmicb.2020.553223
Semiarid regions are apparently low biodiversity environments; however, these environments may host a phylogenetically diverse microbial community associated with plants. Their microbial inhabitants are often recruited to withstand stressful settings and improve plant growth under harsh conditions. Thus, plant-associated microorganisms isolated from semiarid and seasonally dry environments will be detailed in the present review, focusing on plant growth promotion potential and the microbial ability to alleviate plant abiotic stress. Initially, we explored the role of microbes from dry environments around the world, and then, we focused on seasonally dry Brazilian biomes, the Caatinga and the Cerrado. Cultivable bacteria from semiarid and seasonally dry environments have demonstrated great plant growth promotion traits such as plant hormone production, mobilization of insoluble nutrients, and mechanisms related to plant abiotic stress alleviation. Several of these isolates were able to improve plant growth under stressful conditions commonly present in typical semiarid regions, such as high salinity and drought. Additionally, we highlight the potential of plants highly adapted to seasonal climates from the Caatinga and Cerrado biomes as a suitable pool of microbial inoculants to maintain plant growth under abiotic stress conditions. In general, we point out the potential for the exploitation of new microbial inoculants from plants growing in dry environments to ensure a sustainable increase in agricultural productivity in a future climate change scenario.

Keywords: semiarid, seasonally dry environments, plant growth-promoting bacteria, drought, salinity

\section{INTRODUCTION}

Plants can host many microbes in the rhizosphere, endosphere, leaf surfaces, and other tissue compartments, collectively known as the plant microbiome. Many of these plantassociated microbes are known to be able to benefit plant health by positively influencing plant physiology, development, and environmental adaptation (Grover et al., 2011; Mendes et al., 2011; Berendsen et al., 2012). The plant microbial community composition and functions are tightly shaped by environmental factors (Martiny et al., 2006; Taketani et al., 2014, 2017) and changes in root and leaf exudates and other metabolic inputs (Williams and de Vries, 2020). The stress-induced 
enrichment of particular microbes in different host tissues can mediate plant stress tolerance (Liu et al., 2020).

Arid lands cover approximately $30 \%$ of the world's land area. Particularly in semiarid and seasonally dry regions, drought, high temperature, and high salinity are commonly reported abiotic stresses that have a significant impact on the plant-associated microbiota (Kavamura et al., 2013b; Paul and Lade, 2014; Naylor and Coleman-Derr, 2018; Lacerda-Júnior et al., 2019). Plants and microbes have some adaptations and interactions to allow them to survive in these harsh environments and to overcome such harsh conditions (Ngumbi and Kloepper, 2016). Plantassociated bacteria that positively influence plant growth and development are collectively known as plant growth-promoting bacteria (PGPB). Given the current climate change scenario and future predictions of an increase in arid lands (Beck et al., 2018), the prospect of PGPB from semiarid and seasonally dry regions to enhance crop yield under stress conditions has been explored (Kavamura et al., 2013a; Marasco et al., 2013; Shrivastava and Kumar, 2015; Jochum et al., 2019; Selim et al., 2019; Andrade et al., 2020; Santana et al., 2020; Santos et al., 2020).

The best-known mechanisms involved in plant growth promotion are the production of plant phytohormones [such as indoleacetic acid (IAA) and gibberellins] (Bano et al., 2010; Duca et al., 2014; Singh and Jha, 2017), mobilization of insoluble nutrients (P, Fe, and $\mathrm{Zn}$, for example) (Chen et al., 2006; Chauhan et al., 2017), biological control of soilborne pathogens (Dias et al., 2014), biological nitrogen fixation (BNF) (Baldani et al., 2014), and 1-aminocyclopropane-1-carboxylic acid (ACC) deaminase production (Glick et al., 1998; Glick, 2005). Some plant growthpromotion mechanisms (PGPMs), such as exopolysaccharide production (Bomfeti et al., 2011) and higher accumulation of osmoprotective sugars and amino acids (threalose, proline, and betaine) (Naseem et al., 2018), are more specifically involved in plant tolerance to common abiotic stresses found in dry regions (e.g., drought and salinity).

Thus, this review will initially focus on assessing the potential and features of bacteria from semiarid environments worldwide exhibiting plant growth-promoting (PGP) traits to alleviate abiotic stresses. Additionally, we explored the biological diversity of two seasonally dry environments as a prospective microbial inoculant source to promote important crop growth under stress conditions. The Caatinga, an exclusively Brazilian biome, comprises a highly diverse tropical dry forest that faces a seasonal water regime (de Albuquerque et al., 2012; Alvares et al., 2013). The Cerrado, the largest and most taxon-rich savanna in the world, is considered one of 25 global biodiversity hotspots (Myers et al., 2000). Their extensive natural vegetation highly adapted to harsh conditions may harbor new PGPB with beneficial plantmicrobe interactions facing environmental stressors.

\section{PROSPECTS OF PLANT GROWTH-PROMOTING BACTERIA FROM SEMIARID REGIONS}

Plants from semiarid regions are exciting sources of promising PGPB, as they may harbor associated microbes with the potential to alleviate abiotic stress related to dry environments (Shrivastava and Kumar, 2015). For this reason, several studies have focused on isolating and investigating bacteria inhabiting plants adapted to semiarid regions. Regarding the choice of the host as a microbial source, both native plants from semiarid climates (Sorty et al., 2016; El-Kahkahi et al., 2019; Gao et al., 2019) and crop plants (Egamberdieva et al., 2008; Yasmin et al., 2013) grown in semiarid lands have been explored.

Usually, investigation of PGPB from semiarid regions searches for common traits related to direct plant growth promotion such as ACC deaminase activity, nitrogen fixation, phosphate solubilization, IAA production, and siderophore production (Kumar et al., 2014; Wang et al., 2014; Niu et al., 2018; ElKahkahi et al., 2019; Gao et al., 2019; de la Torre-Hernández et al., 2020). However, some studies have also focused on the indirect mechanism of plant growth, such as the biocontrol potential of bacterial isolates (Egamberdieva et al., 2008; Minaxi and Saxena, 2010; Yasmin et al., 2013; Table 1).

Because semiarid areas impose drought and high salinity stresses on plants and the associated bacterial community (Paul and Lade, 2014; Naylor and Coleman-Derr, 2018), strategies to isolate bacteria from plant hosts that can cope with such stresses are desirable. For instance, Niu et al. (2018) isolated bacterial strains from the roots and rhizosphere of foxtail millet (Setaria italica L.), a drought-tolerant crop growing in a semiarid agroecosystem in northeastern China, and they were able to find four isolates with the potential to alleviate drought stress. Similarly, Egamberdieva et al. (2008) isolated 210 rhizobacteria from wheat roots grown in salinized soils in a semiarid climate in Uzbekistan, and they found eight isolates that positively affected wheat plant in vitro growth and that were salt-tolerant.

The prospect of PGPB to alleviate semiarid stresses could benefit from a more targeted approach. Sorty et al. (2016) isolated 79 bacteria associated with nodule, root, stem, leaf, and root surfaces and rhizosphere of Psoralea corylifolia L. grown in a salt-affected semiarid region of India. They found that bacteria isolated from the rhizosphere and rhizoplane showed the highest salt-tolerance ability, probably due to their previous exposure to high salt concentrations in the soil. Such information could guide future studies interested in isolating halotolerant bacteria.

Moreover, in another report, Jochum et al. (2019) designed a novel bioprospecting procedure to screen PGPB capable of rapidly colonizing the rhizosphere and mitigating drought stress in multiple cereal hosts. Initially, they isolated 200 bacteria from the perennial grass rhizosphere of a semiarid environment in Texas, United States. These plants are able to grow vigorously under water stress, so they might foster a microbiome capable of coping with water stress. Then, they conducted a prescreening focusing on the desired host phenotype (onset delay of drought stress symptoms) rather than bacterial phenotype. With such an approach, they were able to find two bacterial isolates that significantly alleviated drought stress symptoms.

In summary, when investigating PGPB from semiarid regions, one should consider: (1) the host choice, evaluating its habitat conditions; (2) prospecting bacterial common PGP traits; (3) prospecting bacterial PGP traits related to dry environment stress 
TABLE 1 | Prospect of plant growth-promoting bacteria from plants growing in semiarid lands and seasonally dry environments and the traits investigated.

\begin{tabular}{|c|c|c|c|c|c|}
\hline Authors & Location & Host Plant & Sample source & Bacterial isolates & PGP traits* \\
\hline $\begin{array}{l}\text { Egamberdieva } \\
\text { et al., } 2008\end{array}$ & Uzbekistan & Triticum aestivum & Rhizosphere & $\begin{array}{l}\text { Acinetobacter sp., Alcaligenes } \\
\text { faecalis, Bacillus cereus, } \\
\text { Enterobacter hormaechei, } \\
\text { Pantoea agglomerans, } \\
\text { Pseudomonas aeruginosa, } \\
\text { Staphylococcus saprophyticus }\end{array}$ & $\begin{array}{l}\text { Antagonistic activities; } \\
\text { Exoenzymatic activities; Indol } \\
\text { Acetic Acid (IAA) production; Salt } \\
\text { tolerance; Temperature tolerance; } \\
\text { Volatile hydrogen cyanide (HCN) } \\
\text { production }\end{array}$ \\
\hline $\begin{array}{l}\text { Fernandes-Júnior } \\
\text { et al., 2015; } \\
\text { Santana et al., } \\
2020\end{array}$ & Brazil & $\begin{array}{l}\text { Tripogonella spicata } \\
\text { (Nees) }\end{array}$ & Root & $\begin{array}{l}\text { Pantoea sp., Bacillus sp., } \\
\text { Enterobacter sp., Rhizobium } \\
\text { sp. }\end{array}$ & $\begin{array}{l}\text { IAA production; nitrogen fixation } \\
\text { under saline conditions }\end{array}$ \\
\hline Gao et al., 2019** & China & Caragana microphylla & Rhizosphere, bulk soil & $\begin{array}{l}\text { Actinobacteria, Firmicutes, } \\
\text { Proteobacteria }\end{array}$ & $\begin{array}{l}\text { 1-aminocyclopropane-1- } \\
\text { carboxylate (ACC) deaminase } \\
\text { activity; IAA production; nitrogen } \\
\text { fixation; phosphate solubilization; } \\
\text { Siderophore production }\end{array}$ \\
\hline $\begin{array}{l}\text { Jochum et al., } \\
2019\end{array}$ & United States & Cynodon spp. & Rhizosphere & Bacillus sp., Enterobacter sp. & $\begin{array}{l}\text { Drought tolerance; } \\
\text { phytohormone production }\end{array}$ \\
\hline $\begin{array}{l}\text { Kavamura et al., } \\
2013 a\end{array}$ & Brazil & $\begin{array}{l}\text { Cactus (Cereus } \\
\text { jamacaru) }\end{array}$ & Root & $\begin{array}{l}\text { Bacillus spp., Pantoea sp., } \\
\text { Virgibacillus sp., Brevibacillus } \\
\text { sp., Arthrobacter sp., } \\
\text { Paenibacillus sp., Gordonia sp., } \\
\text { Cellulosimicrobium sp., } \\
\text { Nocardia sp. }\end{array}$ & $\begin{array}{l}\text { Cellulase production; } \\
\text { exopolysaccharide production; } \\
\text { growth in medium with low water } \\
\text { availability (0.919Aw); HCN } \\
\text { production; IAA production; } \mathrm{NH}_{3} \\
\text { production; phosphate } \\
\text { solubilization; salt tolerance }\end{array}$ \\
\hline $\begin{array}{l}\text { El-Kahkahi et al., } \\
2019\end{array}$ & Morocco & Ceratonia siliqua L. & Rhizosphere & $\begin{array}{l}\text { Bacillus spp., Pseudomonas } \\
\text { gessardii }\end{array}$ & $\begin{array}{l}\text { Cellulase production; chitinase } \\
\text { production; IAA production; } \\
\text { nitrogen fixation; phosphate } \\
\text { solubilization; protease } \\
\text { production }\end{array}$ \\
\hline $\begin{array}{l}\text { Kumar et al., } \\
2014^{\star \star}\end{array}$ & India & Not informed & Rhizosphere & $\begin{array}{l}\text { Agrobacterium tumefaciens, } \\
\text { Bacillus spp., Paenibacillus sp., } \\
\text { Stenotrophomonas sp. }\end{array}$ & $\begin{array}{l}\text { Acetylene reduction; ammonia } \\
\text { excretion; IAA production; } \\
\text { phosphate solubilization; } \\
\text { siderophore production }\end{array}$ \\
\hline $\begin{array}{l}\text { Minaxi and Saxena, } \\
2010\end{array}$ & India & Vigna radiata L. & Rhizosphere & $\begin{array}{l}\text { Burkholderia cepacia, } \\
\text { Pseudomonas fluorescens }\end{array}$ & $\begin{array}{l}\text { Antagonistic activities; chitinase } \\
\text { production; siderophore } \\
\text { production }\end{array}$ \\
\hline Niu et al., 2018 & China & Setaria italica L. & Root & $\begin{array}{l}\text { Arthrobacter spp., } \\
\text { Enterobacter spp., Klebsiella } \\
\text { oxytoca, Ochrobactrum } \\
\text { intermedium, Pantoea spp., } \\
\text { Pseudomonas spp. }\end{array}$ & $\begin{array}{l}\text { ACC deaminase activity; drought } \\
\text { tolerance; exopolysaccharide } \\
\text { production; IAA production; } \\
\text { nitrogen fixation; phosphate } \\
\text { solubilization; siderophore } \\
\text { production }\end{array}$ \\
\hline Sorty et al., 2016 & India & Psoralea corylifolia L. & $\begin{array}{l}\text { Root, shoot and nodule } \\
\text { endophytes, } \\
\text { rhizosphere, rhizoplane, } \\
\text { leaf epiphytes }\end{array}$ & $\begin{array}{l}\text { Acinetobacter sp., Bacillus sp., } \\
\text { Enterobacter sp., } \\
\text { Marinobacterium sp., Pantoea } \\
\text { sp., Pseudomonas sp. } \\
\text { Rhizobium sp., Sinorhizobium } \\
\text { sp. }\end{array}$ & $\begin{array}{l}\text { Exopolysaccharide production; } \\
\text { IAA production; nitrogen fixation; } \\
\text { phosphate solubilization; salt } \\
\text { tolerance; siderophore production }\end{array}$ \\
\hline $\begin{array}{l}\text { de la } \\
\text { Torre-Hernández } \\
\text { et al., } 2020\end{array}$ & Mexico & $\begin{array}{l}\text { Echinocactus } \\
\text { platyacanthus }\end{array}$ & Rhizosphere & $\begin{array}{l}\text { Bacillus spp., Brevibacterium } \\
\text { sp., Cutibacterium sp., } \\
\text { Paenibacillus sp., } \\
\text { Pseudomonas spp., } \\
\text { Stenotrophomonas spp. }\end{array}$ & $\begin{array}{l}\text { Antagonistic activities; IAA } \\
\text { production; phosphate } \\
\text { solubilization; siderophore } \\
\text { production }\end{array}$ \\
\hline Wang et al., 2014** & China & Populus euphratica & Rhizosphere & $\begin{array}{l}\text { Bacillus sp., Pseudomonas sp., } \\
\text { Serratia sp., } \\
\text { Stenotrophomonas sp. }\end{array}$ & $\begin{array}{l}\text { ACC deaminase activity; acetoin } \\
\text { production; IAA production; } \\
\text { nitrogen fixation; phosphate } \\
\text { solubilization; siderophore } \\
\text { production }\end{array}$ \\
\hline Yasmin et al., 2013 & Pakistan & Zea mays & Rhizosphere & Not informed & $\begin{array}{l}\text { Bacteriocin production; } \\
\text { phosphate solubilization; } \\
\text { siderophore production }\end{array}$ \\
\hline
\end{tabular}

\footnotetext{
*PGP traits - Plant growth promotion traits. **Samples collected from both arid and semiarid regions.
} 
alleviation; and (4) using more targeted approaches, focusing either on a particular abiotic stress alleviation or on a specific plant to enhance growth.

\section{EVALUATING THE PLANT GROWTH PROMOTION OF BACTERIAL ISOLATES FROM SEMIARID ENVIRONMENTS}

Bacteria that exhibit several PGP traits-such as nitrogen fixation, phosphate solubilization, phytohormone production, and salt and drought tolerance-become interesting candidates to be evaluated under greenhouse and field conditions aiming for the selection of new plant growth promoters under the harsh environmental conditions of a semiarid climate (Figure 1). Bacterial strains isolated from a particular plant should be tested to promote the growth of the same plant (Arif et al., 2016; Mishra et al., 2016) as well as of an important food crop such as wheat and maize (Wang et al., 2014; Sorty et al., 2016; Jochum et al., 2019; Table 2). The cross-colonization of bacterial isolates is common (Quecine et al., 2012) and has been used to alleviate drought, common abiotic stress in semiarid lands (Marasco et al., 2013).

Bacteria able to promote plant growth under drought stress significantly affect root architecture and/or growth, improving water and nutrient acquisition (Wang et al., 2014; Armada et al., 2016; Jochum et al., 2019). The root improvement can be related to the bacterial production of phytohormones (Glick, 1995) - such as IAA-whereas this trait was noticed in bacteria able to promote plant growth under drought conditions (Armada et al., 2016; Jochum et al., 2019; Selim et al., 2019). However, it is essential to point out that root improvement might also be related to other plant-microbe interaction mechanisms.

Oxidative stress, characterized by the enhanced production of various reactive oxygen species (ROS), is one of the main causes of plant injury under drought stress (Hasanuzzaman et al., 2013; Ngumbi and Kloepper, 2016). Plants maintain ROS homeostasis by producing enzymes and antioxidant compounds (Carvalho, 2008). In this context, bacteria capable of reducing harmful plant oxidative effects are also potential candidates to increase drought tolerance. Plants inoculated with PGPB exhibited decreased production of malondialdehyde, a biochemical marker for oxidative lipid injury induced during drought (Armada et al., 2016; Selim et al., 2019).

Previous reports have shown an increase in antioxidant enzymes in plants inoculated with PGPB under drought conditions (Ngumbi and Kloepper, 2016). However, plants inoculated with bacterial isolates from semiarid regions have shown different trends relative to antioxidant system activity.

The antioxidant activities of superoxide dismutase, catalase, and ascorbate peroxidase enzymes in Lavandula dentata depend on the single or co-inoculation of different arbuscular mycorrhizal fungi with endophytic Bacillus thuringiensis. In particular, the interaction of the arbuscular mycorrhizal fungal mixture and $B$. thuringiensis induced the highest activity of some antioxidant plant enzymes and increased mycorrhizal development (Armada et al., 2016). Likewise, actinobacteria also increased the level of molecular antioxidants (total ascorbate, glutathione, tocopherols, phenolic acids, and flavonoids) and improved the growth and photosynthesis of maize grown under water-deficit conditions (Selim et al., 2019). In contrast, maize seedlings inoculated with Pseudomonas spp. showed lower antioxidant enzyme activities (ascorbate peroxidase, catalase, and glutathione peroxidase) under drought stress. The reduced drought stress effect on the antioxidant activity in inoculated seedlings may be explained by the protective effect granted by other bacterial traits that avoid dehydration (Sandhya et al., 2010). Clearly, the plant antioxidant system is essential to control the damage of ROS; however, more studies are necessary to support the mechanisms behind plant oxidative stress alleviation under drought conditions by PGPB.

Salt stress is another important abiotic stress limiting the productivity of crop plants in arid and semiarid conditions. Saline soils increase the levels of ethylene and ACC, causing plant damage (Kukreja et al., 2005). Interestingly, the inoculation of ACC deaminase-producing bacteria can help plants cope with salinity by reducing ethylene levels (Paul and Lade, 2014).

Indigenous bacteria of nine agroclimatic zones from India were selected based on their salt tolerance ability and ACC deaminase activity. Eighty-eight percent of isolates from the semiarid region were salt-tolerant, and the isolate Bacillus megaterium NBRI 20M exhibiting the highest ACC deaminase activity was capable of alleviating maximum salinity stress in rice (Misra et al., 2017). However, it is important to point out that other isolates with high production of IAA and low activity of ACC deaminase were responsible for significant increases in rice seedling biomass (Misra et al., 2017). These findings make it clear that despite the proven growth promotion mediated by ACC deaminase activity in decreasing ethylene levels (Glick, 2005), it is not easy to disentangle the actions and effects of each mechanism when using multitrait PGPB.

Plant growth promotion by multitrait PGPB can occur through the action of more than one mechanism at a time. In our study, several bacterial isolates from semiarid regions showed some PGP traits (Minaxi et al., 2012; Armada et al., 2016; Selim et al., 2019). It is also common to look for more than one trait when prospecting for potential PGPB (see Table 1). However, more studies should focus on understanding the mechanisms used independently by bacteria to alleviate abiotic stresses. One interesting approach that might be used to investigate the molecular mechanisms related to plant growth promotion in bacteria is the knockout of a gene involved in the metabolism of such traits. This approach has been successfully used to investigate genes related to IAA metabolism (Idris et al., 2007; Malhotra and Srivastava, 2008) and ACC deaminase (Li et al., 2000).

Finally, when looking for a successful PGPB, field experiments are an important approach to evaluate how they will perform under real conditions. Several bacterial isolates were able to promote plant growth of some crops under semiarid field conditions. Bacillus sp. RM-2 enhanced the yield 


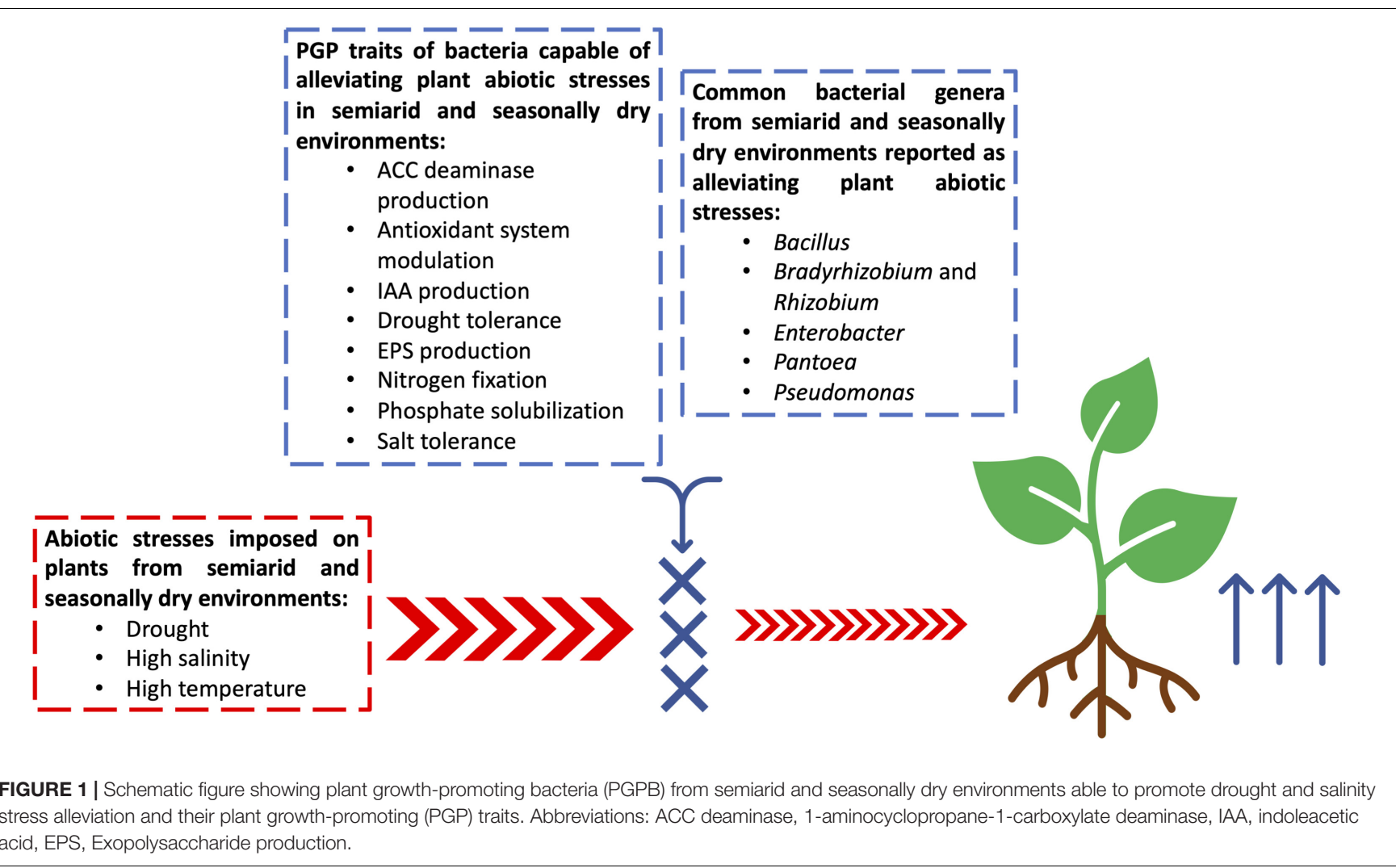

parameters of cowpea plants (number of pods and seeds and grain yield), showing several PGP traits (Minaxi et al., 2012). Actinobacterial inoculants were able to increase soil fertility and improve fruit yield in date palm plants. The fruits showed higher levels of valuable phytochemicals, suggesting that inoculation improves production and functional food value (AbdElgawad et al., 2019). Additionally, the Bacillus and Pseudomonas genera promoted carob tree plant growth by enhancing plant height, root length, and fresh weight of the aerial and root parts in a field experiment (El-Kahkahi et al., 2019).

\section{BRAZILIAN SEMIARID REGION AND SEASONALLY DRY ENVIRONMENTS: A PROMISING SOURCE OF POTENTIAL PLANT GROWTH-PROMOTING BACTERIA}

Tropical countries housing peculiar ecosystems evolving under relatively harsh environmental conditions are expected to harbor unique and diverse biota and remarkable microbes. Especially in Brazil, the Caatinga tropical dry forest and Cerrado savanna are dryland ecosystems with a high diversity of native plant species adapted to thrive in a seasonally variable climate, high temperatures, high levels of ultraviolet radiation and salinity, and low-nutrient soils (Damasco et al., 2018; Figure 2). Due to their high biological diversity even under peculiar climate conditions, these Brazilian ecosystems may be explored to decipher plant-microbiome interactions to confront abiotic stresses and identify potential new PGPBs (Figure 3).

\section{PLANT-ASSOCIATED BACTERIA FROM THE CAATINGA BIOME AND THEIR PLANT GROWTH-PROMOTING POTENTIAL UNDER DROUGHT STRESS}

As shown in the previous sections, the beneficial microbes naturally associated with plants growing in semiarid environments have attracted increased interest. They represent an unexploited reservoir for biological agents against biotic stresses that endanger agricultural ecosystems. The Caatinga is a stepic savanna found exclusively in the heart of the Brazilian semiarid belt in the northeast region (Figure 2). The Caatinga biome harbors the largest and most diverse seasonal tropical dry forest in South America, covering 844,453.00 km² (approximately $11 \%$ of the Brazilian territory) (Beuchle et al., 2015; Queiroz et al., 2017). Its general ecophysiognomy presents a heterogeneous mosaic of drought-tolerant plants: succulents, thorny deciduous trees, and shrubs with xerophytic characteristics (Figure 2). The set of contrasting physical and climatic factors provides a high diversity of vegetation types. In this huge extension, Caatinga harbors (according to our current knowledge) 4,657 angiosperm species, of which 913 (19.6\%) are 
TABLE 2 | Plant growth-promoting bacteria from semiarid lands and seasonally dry environments, and their role in alleviating abiotic stresses in crops.

\begin{tabular}{|c|c|c|c|c|c|c|}
\hline Authors & Location & Host plant & Sample source & Tested plant & Bacterial isolates & $\begin{array}{l}\text { Conditions of } \\
\text { experiment }\end{array}$ \\
\hline AbdElgawad et al., 2019 & Saudi Arabia & $\begin{array}{l}\text { Phoenix dactylifera } \\
\text { L. }\end{array}$ & Rhizosphere & $\begin{array}{l}\text { Phoenix dactylifera } \\
\text { L. }\end{array}$ & Actinobacteria isolates & $\begin{array}{l}\text { Field in semiarid } \\
\text { climate }\end{array}$ \\
\hline Arif et al., 2016 & Pakistan & $\begin{array}{l}\text { Helianthus annuus } \\
\text { L. }\end{array}$ & Rhizosphere & $\begin{array}{l}\text { Helianthus annuus } \\
\text { L. }\end{array}$ & Pseudomonas aeruginosa & $\begin{array}{l}\text { Presence or } \\
\text { absence of } \\
\text { Nitrogen }\end{array}$ \\
\hline Armada et al., 2016 & Spain & Not informed & Soil & Lavandula dentata & Bacillus thuringiensis & Drought stress \\
\hline Jochum et al., 2019 & United States & Cynodon spp. & Rhizosphere & $\begin{array}{l}\text { Triticum aestivum, } \\
\text { Zea mays }\end{array}$ & Bacillus sp., Enterobacter sp. & Drought stress \\
\hline El-Kahkahi et al., 2019 & Morocco & Ceratonia siliqua L. & Rhizosphere & Ceratonia siliqua L. & $\begin{array}{l}\text { Bacillus spp., Pseudomonas } \\
\text { gessardii }\end{array}$ & $\begin{array}{l}\text { Field in semi-arid } \\
\text { conditions }\end{array}$ \\
\hline Kavamura et al., 2013a & Brazil & $\begin{array}{l}\text { Cereus jamacaru } \\
\text { (Cactus) }\end{array}$ & Rhizosphere & Zea mays & Bacillus spp. and Pantoea sp. & $\begin{array}{l}\text { Greenhouse } \\
\text { experiment/drought } \\
\text { stress }\end{array}$ \\
\hline Minaxi et al., 2012 & India & Vigna radiata & Rhizosphere & Vigna unguiculata & Bacillus sp. & $\begin{array}{l}\text { Field in semiarid } \\
\text { conditions }\end{array}$ \\
\hline Minaxi and Saxena, 2010 & India & Vigna radiata & Rhizosphere & Vigna radiata & $\begin{array}{l}\text { Burkholderia cepacia, } \\
\text { Pseudomonas fluorescens }\end{array}$ & Biocontrol \\
\hline Mishra et al., 2016 & India & $\begin{array}{l}\text { Foeniculum vulgare } \\
\text { Mill. }\end{array}$ & Soil & $\begin{array}{l}\text { Foeniculum vulgare } \\
\text { Mill. }\end{array}$ & Bacillus spp., Planococcus sp. & Field experiment \\
\hline Misra et al., 2017 & India & Agricultural fields & Soil & Oryza sativa & $\begin{array}{l}\text { Acinetobacter Iwoffii, } \\
\text { Arthrobacter defluvii, Bacillus } \\
\text { spp., Jeotgalicoccus huakuii, } \\
\text { Lysinibacillus fusiformis, } \\
\text { Oceanobacillus picturae, } \\
\text { Staphylococcus cohnii }\end{array}$ & Salinity stress \\
\hline Sandhya et al., 2010 & India & Crop plants & Rhizosphere & Zea mays & Pseudomonas spp. & Drought stress \\
\hline Santana et al., 2020 & Brazil & Tripogonella spicata & Roots & Zea mays & $\begin{array}{l}\text { Enterobacter sp., Bacillus sp., } \\
\text { and Rhizobium sp., }\end{array}$ & Drought stress \\
\hline Selim et al., 2019 & Saudi Arabia & Panicum turgidum & Rhizosphere & Zea mays & Streptomyces sp. & Drought stress \\
\hline Sorty et al., 2016 & India & Psoralea corylifolia & $\begin{array}{l}\text { Root, shoot and } \\
\text { nodule endophytes, } \\
\text { rhizosphere, } \\
\text { rhizoplane, leaf } \\
\text { epiphytes }\end{array}$ & Triticum aestivum & $\begin{array}{l}\text { Acinetobacter sp., Bacillus sp., } \\
\text { Enterobacter sp., } \\
\text { Marinobacterium sp., Pantoea } \\
\text { sp., Pseudomonas sp. } \\
\text { Rhizobium sp., Sinorhizobium } \\
\text { sp. }\end{array}$ & Salinity stress \\
\hline Wang et al., 2014 & China & Populus euphratica & Rhizosphere & Triticum aestivum & $\begin{array}{l}\text { Bacillus sp., Pseudomonas sp., } \\
\text { Serratia sp., } \\
\text { Stenotrophomonas sp. }\end{array}$ & Drought stress \\
\hline
\end{tabular}

endemic (Zappi et al., 2015). During the dry season, most plant species lose their leaves, and white tree trunks prevail in the landscape (Salgado et al., 2015).

Although plants inhabiting the Caatinga semiarid lands possess inherent traits for survival in a harsh climate, the plant-associated microbiome has also been suggested to play an essential role in plant fitness under seasonal water availability and extended drought periods. This point is a neglected topic in plant microbiology, but some recent research has revealed the potential of bacteria associated with Caatinga native plants as inoculants for plant growth promotion under drought conditions.

Water availability is known to be able to shape the microbial community composition, both in bulk soil (Lacerda-Júnior et al., 2019) and the rhizosphere of Caatinga native species (Kavamura et al., 2013b). Using culture-independent analyses, Kavamura et al. (2013b) showed the rhizosphere microbiome seasonal pattern from Cereus jamacaru (Figures 2F,G), a welldistributed native cactus in the Caatinga biome. The phyla Actinobacteria and Firmicutes (mainly the Bacillus genus) were significantly enriched during the dry season, whereas the phyla Proteobacteria and Bacteroidetes were more abundant in the rainy season. However, although shifts in the rhizosphere microbial community driven by seasonality are also evidenced in other rhizosphere systems (Ibekwe et al., 2017; Liang et al., 2019), their functional role in supporting plant development under arid and semiarid ecosystems is unclear.

One of the hypotheses is that root-associated microorganisms have developed cellular mechanisms for water stress tolerance that lead to plant protection against the negative effects of desiccation (Naseem et al., 2018; Naylor and ColemanDerr, 2018). To test this hypothesis, Kavamura et al. (2013a) investigated for the first time the potential of cacti root-associated bacteria from Brazilian semiarid lands to promote maize growth 


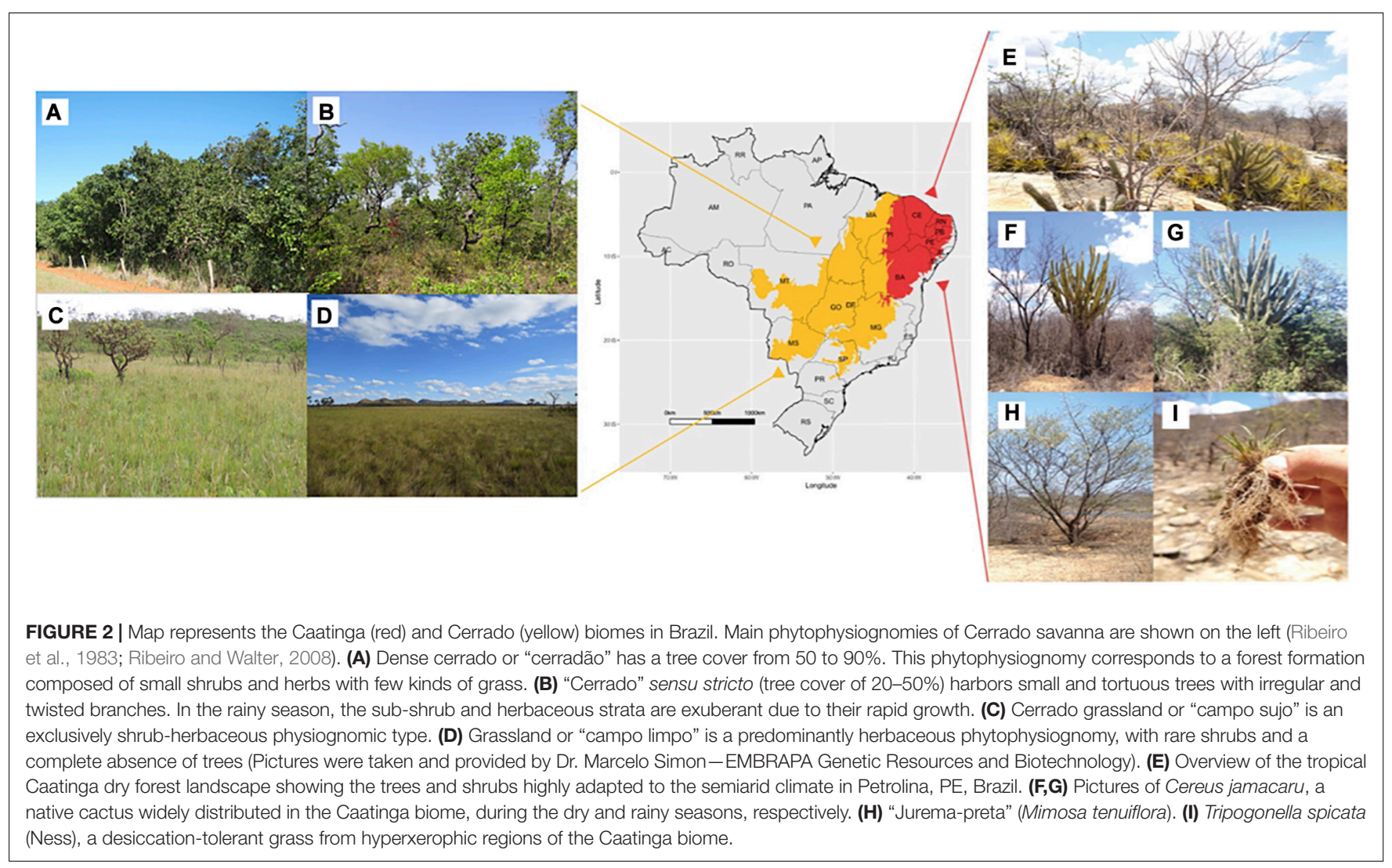

(Zea mays) under water stress. Most cactus isolates showed in vitro PGP traits, exopolysaccharide production, and the ability to grow in a medium with reduced water availability $(0.919$ Aw) (Tables 1, 2). The inoculation of two xerotolerant cactusassociated Bacillus spp. (LMA52 and LMA3) and Pantoea sp. in maize seedlings protected against the negative effects of drought and increased the leaf area, stalk length, and shoot dry biomass under water stress. These results indicate that selecting osmotolerant microorganisms with common PGP traits is a promising approach to prospecting potential PGPB to mitigate plant drought stress. More recently, other Bacillus spp. from the cactus rhizosphere of Brazilian Caatinga showed the potential to promote maize growth under drought conditions (Santos et al., 2020). These reports reveal cacti as an underexploited source of PGPB to crops in agricultural practices under drought conditions.

Regarding the plant mechanisms to cope with water-limited conditions, desiccation-tolerant (DT) plants or "resurrection plants" can desiccate and survive during severe and long drought periods (Tuba and Lichtenthaler, 2011). Tripogonella spicata (Nees) P.M. Peterson and Romasch (Figure 2), a DT wild grass naturally found at rock outcrops in hyperxerophilic regions of the Caatinga biome (Gaff, 1987), possesses specialized physiologic strategies to recover active metabolism after long drought periods (Aidar et al., 2017). However, the role of microbes in helping resurrection plants tolerate and recover photosynthetic activity after long dehydration periods is still not well understood. Then, Fernandes-Júnior et al. (2015) isolated and tested the potential of diazotrophic PGPB from T. spicata roots to promote plant growth. Five isolates were able to increase rice root and/or shoot growth compared with plants inoculated with Azospirillum brasilense Ab-V5 (Hungria et al., 2010), a commercial strain of rice inoculants in Brazil. Two isolates identified as Pantoea sp. and Bacillus sp. increased rice growth at the same rate as plants that received full $\mathrm{N}$ fertilization. Furthermore, Santana et al. (2020) showed that Enterobacter sp., Bacillus sp., and Rhizobium sp., isolated from T. spicata, were also able to improve some plant growth and gas exchange parameters in sorghum growing under drought conditions (Tables 1, 2). Although these bacterial groups have already been shown to be efficient inoculants for sorghum (da Silva et al., 2018; Antunes et al., 2019), their ability to attenuate the adverse effects of drought and promote sorghum growth under drought had not been revealed. Interestingly, these T. spicata isolates showed diazotrophic capacity in a culture medium supplemented with up to $1.27 \mathrm{~mol} \mathrm{~L}^{-1} \mathrm{NaCl}$ (Table 1; Fernandes-Júnior et al., 2015), which suggests that the beneficial effects of BNF may be supported around the plant environment under water-deficit conditions. These results indicate that the selection of strains able to show active PGP traits under salt and water stress conditions may be a rational strategy to identify beneficial microbes to help plants cope with harsh environments. In contrast to microbes thriving in common lands, the plant-associated microbiome from dry ecosystems has been selected based on phenotypic or genomic attributes related to a more rigorous stress response regulation of their hosts. 


\section{CAATINGA}

Stepic most diverse seasonal tropical dry I_ _ forest in South America

T. $-\overline{4}, 657$ Angiosperm species with 913 (19.6\%) endemic species

. > 600 legume species

- - - - - - - - - -

- Bacterial strains from native species

alleviating drought symptoms in

crops

I. Desiccation-tolerant plants harbor

I potential PGPB with drought-tolerant

I traits

I. $\mathrm{N}$ cycle is highly dependent of the

I BNF in the rainy season

I. Bradyrhizobium, Paraburkholderia,

I and Rhizobium are the main rhizobia

I genera with high $\mathrm{N}_{2}$-fixing capacity

ニニニニニニニニニニニニュ

I B. yuanmingense $B R 3267$ to $B N F$ on I_ _ cowpea

FIGURE 3 | Schematic figure illustrating the main characteristics and the potential of the Brazilian Cerrado and Caatinga biomes as a promising source for prospecting for new plant growth-promoting bacteria (PGPB) with commercial application in agriculture. Abbreviation: BNF, biological nitrogen fixation.
The largest and most taxon-rich savanna in the world and the second-largest biome in Brazil

I _ - - - biome in Brazil _ - _ J

- 12,097 Angiosperm species with 4,252 (35.1\%) endemic species

- One of 25 global bio-diversity

-

- World's largest agricultural frontier

- Soil with low $\mathrm{N}$ and $\mathrm{P}$ concentration provides a potential niche to explore new PGPB capable of increasing the nutrient availability

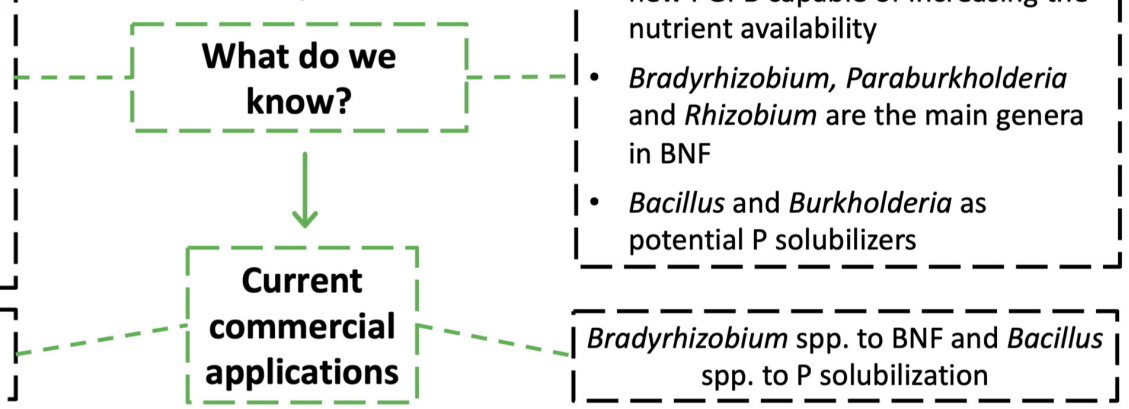

The biological process related to vegetative desiccation tolerance is exhibited by less than $0.2 \%$ of vascular plant species. In addition to T. spicata, several other DT plants, such as the pteridophyte Selaginella spp. (Selaginellaceae), Vellozia cenerascens (Velloziaceae), and Nanuza plicata (Velloziaceae), are found in the Caatinga biome. These data show that plants from Caatinga semiarid areas display a promising niche for isolating novel beneficial microbes with remarkable plant growth-promoting rhizobacteria traits. Research efforts to study the indigenous microbes associated with these species open possibilities for prospecting for new chemical and biological agents to improve the growth of different crop species in dry agricultural lands.

\section{LEGUME-RHIZOBIA ASSOCIATIONS IN THE CAATINGA BIOME: DIVERSITY AND THEIR POTENTIAL EXPLORATION}

Legume plants are the unique family with the ability to establish mutualistic associations with "rhizobia," a collective term given to root/stem-associated bacteria that form nodule structures to the BNF. All rhizobia are members of the phylum Proteobacteria within the classes $\alpha$ - and $\beta$-proteobacteria, also known as $\alpha$ - and $\beta$-rhizobia (Peix et al., 2015). A recent review by Wang (2019) listed 190 species of rhizobia divided into 21 nodulating genera. However, this number is continuously increasing, mainly because new rhizobial species are frequently described.

There is a lack of knowledge regarding the diversity of indigenous rhizobia from native legume species of the Caatinga biome. However, studies evaluating the rhizobial diversity in Caatinga native plant roots have been published in the last few years, indicating the existence of potential new taxa. Genetic analyses of the rhizobial culture collections isolated from Mimosa spp. through amplified ribosomal DNA restriction techniques reveal high diversity and low similarities with several known reference isolates (Teixeira et al., 2010; de Freitas et al., 2014). Likewise, Martins et al. (2015) showed that Mimosa caesalpinifolia nodulates primarily with Paraburkholderia spp. in pristine Caatinga areas. Interestingly, the $16 \mathrm{~S}$ ribosomal RNA gene analyses indicated that some of them were not closely related to the reference strains available in the GenBank database.

From the same legume, de Oliveira et al. (2019) compared the taxonomic diversity of Paraburkholderia from different Brazilian regions using the multilocus sequence analysis approach. The bacterial members isolated from the semiarid region in the Caatinga biome diverged from those in other biomes. $\beta$-Rhizobia from drylands were related to Paraburkholderia diazotrophica or Trinickia symbiotica, whereas bacteria isolated from Rio de 
Janeiro state (far from the Brazilian drylands) were closely related to the Paraburkholderia sabiae and Rhizobium genera. Furthermore, rhizobial isolates from Caatinga drylands were more efficient in increasing plant biomass in gnotobiotic inoculation assays. These results corroborate dos Reis Junior et al. (2010), who described, for the first time, the nodulation of Mimosa spp. by Paraburkholderia (Syn. Burkholderia) in Caatinga and Cerrado Brazilian biomes. A large diversity of Paraburkholderia also nodulate other Mimosoid legumes. In the case of Calliandra, although the majority of the $\beta$-rhizobia were related to Paraburkholderia nodosa, some isolates were not related to known rhizobia from Mimosa hosts (Silva et al., 2019). Bournaud et al. (2013) also isolated both $\beta$ - and $\alpha$-rhizobia in the genera Paraburkholderia and Rhizobium, respectively, from Piptadenia viridiflora growing in the Caatinga biome. These results point to the large diversity of the nodulation patterns of mimosoid legumes from Brazilian drylands, showing vast potential to be explored in the search for new PGPB.

The diversity and ecology of rhizobial papilionoid native legumes in Caatinga are poorly understood. In recent years, bacterial isolation efforts have shown the high biodiversity and biotechnological potential of some rhizobial species. Erythrina velutina, also known as "mulungu," is an iconic Brazilian tree with several potential applications for sustainable use, such as ethnobotanical and traditional medical applications. Regarding the production of healthy mulungu seedlings, the selection of efficient rhizobial isolates is desirable. Studies assessing the diversity and symbiotic potential of mulungu rhizobia indicated that E. velutina nodulates mainly with $\alpha$ - (Rhizobium spp. and Bradyrhizobium spp.) rather than $\beta$-rhizobia (Paraburkholderia spp.), but both classes are found in mulungu nodules (Menezes et al., 2016, 2017; Rodrigues et al., 2018). Considering the symbiotic efficiency, the genera Rhizobium and Bradyrhizobium encompass promising bacteria with superior symbiotic efficiency compared with the other native isolates and non-inoculated treatments (both with sterile and non-sterile substrates).

Compared with the Papilionoideae and Mimosoideae clades, the Caesalpinoideae clade has fewer nodulating members, comprising approximately $25 \%$ of the members within this group (Lewis et al., 2005). For this reason, it is more challenging to find nodulating Caesalpinioideae than Papilionoideae and Mimosoideae in pristine areas. In Caatinga, there is little information about the diversity and efficiency of rhizobia from the Caesalpinioideae family. In a recent survey, dos Santos et al. (2017) isolated several rhizobial isolates from Chamaecrista spp. collected in several areas of Bahia state in the heart of Brazilian drylands. The molecular evaluation based on $16 \mathrm{~S}$ ribosomal RNA, housekeeping, and symbiosis gene sequencing indicated that they belonged to the Bradyrhizobium genus. The taxonomic positioning based on the multilocus sequence analysis approach showed that most isolates (12 of 16 bacteria) were clustered in a separated clade that was not related to classical Bradyrhizobium elkanii and Bradyrhizobium japonicum taxonomic superclades. Overall, these results indicate that diverse rhizobia can nodulate different legumes, even those of closely related species.

Given that the Caatinga biome has (until now) more than 600 legume species, its expected rhizobial diversity is still not revealed. Efforts to isolate and identify these bacteria will probably lead to the description of several new taxa and exploration of potential PGPB traits.

In agricultural systems, several legumes are cropped in the Brazilian semiarid belt (the agricultural lands initially covered by the Caatinga biome), mainly in low-income family based production systems. Among these legumes, cowpea (Vigna unguiculata) is one of the most used, being an important crop in the economy, culinariness, and culture of the people living in the Brazilian semiarid region. For cowpea, there are four Bradyrhizobium spp. strains used for commercial inoculant production in Brazil. Among these strains, Bradyrhizobium yuanmingense BR 3267 was officially recommended in 2004 and is currently the most commonly used in Brazil (da Silva et al., 2012). This strain was isolated from a cowpeaproducing field in Petrolina, Pernambuco state, in the heart of the Brazilian dryland (Martins et al., 2003) is highly competitive for nodulation sites, tolerant to abiotic stresses, and shows the ability to fix high amounts of nitrogen, either under rain-fed or irrigated conditions in the Brazilian semiarid region (Martins et al., 2003; Marinho et al., 2014). Along with several promising studies on selecting PGP microbes in the Caatinga biome, the commercial use of the native strain B. yuanmingense BR 3267 shows the potential of the Brazilian semiarid region as a source of efficient microbes for agricultural uses.

\section{FIELD ASSESSMENT OF BIOLOGICAL NITROGEN FIXATION IN PRISTINE AND RECOVERED CAATINGA AREAS}

It is a challenge to associate the diversity of rhizobia associated with a given tree species and the efficiency of fixing $\mathrm{N}$ under field conditions. Among the methodological approaches used to assess the $\mathrm{N}$ fixation of native legumes in the Caatinga biome, we can highlight the natural abundance of ${ }^{15} \mathrm{~N}$. Briefly, this approach quantifies, using mass spectrometry, the amounts of ${ }^{15} \mathrm{~N}$ and ${ }^{14} \mathrm{~N}$ in $\mathrm{N}_{2}$-fixing and $\mathrm{N}_{2}$-non-fixing species, whereas this difference is used to calculate the total $\mathrm{N}$ derived from the atmosphere (fixed) in target species. Then, together with the plant biomass and total $\mathrm{N}$ accumulation, the $\mathrm{N}$ incorporated in the system (in $\mathrm{kg} \mathrm{N} \mathrm{ha}{ }^{-1}$, for example) is estimated (Boddey et al., 2000).

Teixeira et al. (2006) published the first report of BNF quantification in Brazilian Caatinga fields. The authors investigated the contribution of BNF to $\mathrm{N}$ nutrition in Cratylia mollis. The results indicated that in the rainy season, C. mollis presented up to $86 \%$ of $\mathrm{N}$ derived from the atmosphere, whereas in the dry season, the amount of fixed $\mathrm{N}$ reached $27 \%$, indicating an apparent seasonal effect on the BNF efficiency.

de Freitas et al. (2010) and de Souza et al. (2012) estimated that the contribution of BNF in the three legumes (Mimosa tenuiflora, Mimosa arenosa, and Piptadenia stipulacea) ranged from 6 to $11 \mathrm{~kg} \mathrm{~N} \mathrm{ha}^{-1}$ year $^{-1}$ in pristine Caatinga areas. These low amounts were associated with a low density of $\mathrm{N}_{2}$-fixing species. In contrast, the authors verified a more significant contribution 
of $\mathrm{N}_{2}$-fixing legumes in Caatinga areas under natural recovery (amount of $130 \mathrm{~kg}$ fixed $\mathrm{N} \mathrm{ha}^{-1}$ year $^{-1}$ ) due to the high density of fixing legumes, mainly $M$. tenuiflora. These results indicate the contribution of rhizobia-legume associations to nitrogen incorporation in natural systems in semiarid Brazilian areas, even with low successional stages.

Furthermore, soil parameters and atmospheric temperature also influence the total amount of $\mathrm{N}$ fixed in Caatinga drylands. The total amount of phosphorus in soils is significantly correlated with the $\mathrm{N}$ derived from the atmosphere (biologically assimilated) in pristine and recovering areas (da Silva et al., 2017). This information is important to soil management projects aimed at the recovery of degraded dryland areas. Similarly, de Freitas et al. (2015) showed high $\mathrm{N}$ fixation in areas with higher temperatures than the colder regions from the Brazilian Caatinga. Rainfall did not influence the isotopic signals, indicating the positive influence of temperature rather than rainfall on the $\mathrm{N}$ fixation process.

Such studies are essential because Caatinga biome degradation is an ongoing problem, and the use of environmentally friendly solutions is needed. Further research should focus on soil management approaches that consider both microbiota and plant diversity to increase fundamental nutrient availability.

\section{BRAZILIAN CERRADO: A TROPICAL SAVANNA HOTSPOT}

The Cerrado, the second largest biome of the Brazilian territory, covers approximately 2 million $\mathrm{km}^{2}$ (Figure 2 ) and is considered the largest and most taxon-rich savannah in the world (Furley, 1999; Myers et al., 2000). The Cerrado harbors approximately 4,200 endemic plant species (Zappi et al., 2015) and a wide range of animals and microorganisms and is considered one of 25 global biodiversity hotspots (Myers et al., 2000). This biome comprises 11 different types of phytophysiognomies, including forests, savannas (shrublands), and grasslands (Ribeiro and Walter, 1998). The typical phytophysiognomy, the Cerrado "sensu stricto," is composed of a mix of grasses, bushes, and small trees with twisted trunks (Mendes et al., 2012; Figure 2). According to the extensive flora diversity estimated by Zappi et al. (2015) in the Brazilian Cerrado, the degree of endemism is higher than in the Amazon rainforest, comprising 12,097 angiosperm species with 4,252 (35.1\%) endemic. The main families are Asteraceae $(1,216$ species), Fabaceae $(1,207)$, Orchidaceae (727), Poaceae (648), Melastomataceae (484), Eriocaulaceae (461), Rubiaceae (406), Euphorbiaceae (386), Malvaceae (334), and Apocynaceae (293) (Zappi et al., 2015).

The climate of the Cerrado biome is characterized by hightemperature averages $\left(22-27^{\circ} \mathrm{C}\right)$, rainfall $(800-1,600 \mathrm{~mm})$, and solar radiation (475-500 $\mathrm{Cal} \mathrm{cm}^{-2} \mathrm{day}^{-1}$ ) (Adamoli et al., 1986; Ratter et al., 1997). Despite the high amount of rainfall, the Cerrado presents a great seasonal contrast between the dry season and the rainy season. The seasonal climate has a strong influence on vegetation phenology. During the dry season, some plants lose all or part of their leaves, increasing the soil biomass and biogeochemical processes in the rainy season (Klink and Solbrig, 1996; Ratter et al., 1997).

Cerrado soils are highly weathered, acidic, deficient in nutrients, and rich in iron and aluminum oxides, supporting only adapted vegetation (Adamoli et al., 1986; Ruggiero et al., 2002). Consequently, nutrient cycling in the Cerrado is a key process regulating ecosystem development and primary productivity (Bustamante et al., 2004). The peculiar soil characteristics such as smooth topography, well-drained, not prone to crusting or compaction, associated with the technological advances in agriculture in the last 40 years, have made the Cerrado one of the world's largest agricultural frontiers and the leading grain production area in Brazil (Machado and Silva, 2001). However, a high proportion of this biome has been converted into pasture and agricultural fields (Marris, 2005). Land-use mapping revealed that remnant natural vegetation covered approximately 54\% of the Cerrado in 2017 (Strassburg et al., 2017).

In addition to the tremendous ecological and economic importance of this biome, little is currently known about its biodiversity, especially its microbial communities. The conversion of natural to agricultural areas in the Cerrado can affect the soil microbial communities and their associated biological processes as a result of changes in soil structure, water content, temperature fluctuations, organic matter and nutrient contents, $\mathrm{pH}$, introduction of plant species, and agrochemical inputs (Castro et al., 2008, 2016; Quirino et al., 2009; Araujo et al., 2012; Souza et al., 2016; de Araujo et al., 2017a,b). Metagenomic analysis showed that microbial communities in agricultural soils have the genetic potential to degrade available carbon and aromatic compounds and the metabolism of $\mathrm{N}, \mathrm{P}$, and $\mathrm{S}$, probably in response to the use of fertilizers. In contrast, soils under native vegetation showed a higher number of sequences related to dormancy and sporulation and unknown functions, indicating the possibility of finding new functions and genes (Souza et al., 2016). Another interesting finding from this study was the high number of sequences related to the genus Bradyrhizobium in the agricultural soils, in contrast to the higher abundance of Rhizobium in the undisturbed Cerrado. The presence of Rhizobium species that are tolerant of acidity and other stressful environmental conditions indicates adaptation to the particular edaphoclimatic characteristics of this biome (Ribeiro et al., 2012).

In this context, the peculiar Cerrado soil characteristics combined with high plant diversity provide a potential niche to explore new PGP microbes, especially those capable of increasing availability and nutrient use efficiency, particularly $\mathrm{N}$ and $\mathrm{P}$.

\section{BIOLOGICAL NITROGEN FIXATION IN BRAZILIAN CERRADO LANDS}

Tropical savannas are $\mathrm{N}$-limited systems, and the $\mathrm{N}$-cycle depends on the inputs from BNF. A peculiar characteristic of these ecosystems is the high diversity of herbaceous and woody leguminous species associated with native microbiota, including 
rhizobial strains. More than 1,200 Fabaceae species were documented within the 11 different types of phytophysiognomies in the Brazilian Cerrado. Due to this high diversity, the rhizobial diversity in this biome is expected to be very high.

Mimosa is the most diverse genus of Fabaceae in Brazil and one of the most studied regarding the association of Cerrado native plants with rhizobia. Indeed, Mimosa is now used as a model for studies involving these symbiotic relationships in natural ecosystems. Studies carried out with these plants have demonstrated that $\beta$-proteobacteria ( $\beta$-rhizobia) play a key role in nitrogen fixation in association with leguminous plants (Pires et al., 2018). Previous studies have shown that bacteria from the genus Paraburkholderia (formerly Burkholderia) are the primary symbionts of Mimosa species in the Cerrado (Elliott et al., 2007; Bontemps et al., 2010; dos Reis Junior et al., 2010). Pires et al. (2018) indicate that soil factors such as $\mathrm{pH}$, nitrogen, organic matter, and fertility seem to prevail over the host identity, determining the predominance of certain types of rhizobia ( $\alpha$ - and $\beta$-proteobacteria), influencing the establishment of symbiotic relationships.

Dall'Agnol et al. (2016) showed that P. nodosa was the main $\mathrm{N}_{2}$-fixing species trapped by promiscuous common bean (Phaseolus vulgaris L.) in the Brazilian "Cerradão." "Cerradão" is a type of Cerrado phytophysiognomy that is a forest formation with xeromorphic aspects, and despite the forest-like vegetation, the floristic composition is similar to the Cerrado sensu stricto (Figure 2). The predominance of $P$. nodosa might be associated with the edaphic properties of the Cerrado biome, which is characterized by acidic soils with high Al saturation and low nutrient content (Dall'Agnol et al., 2016). Mercante et al. (2017) used Leucaena (Leucaena leucocephala) and common bean (Phaseolus vulgaris L.) to trap nodules for further rhizobial isolation using Cerrado soils from different locations. This work resulted in the identification of several highly symbiotically efficient Rhizobium spp. strains with competitive ability and genetic stability. Common bean inoculation with these strains showed economic viability and high potential to obtain a more effective and suitable inoculant for commercial purposes.

The exploration of the amazing diversity and native and/or naturalized microorganisms adapted to Cerrado edaphoclimatic conditions is a key strategy for the development of highly efficient inoculants to be used in agriculture. An outstanding example is the case of soybean crops, in which new efficient and adapted Bradyrhizobium strains have been selected and isolated from areas previously inoculated, showing greater $\mathrm{N}_{2}$ fixation capacity, higher competitiveness, and tolerance to frequently stressful tropical conditions (Hungria and Mendes, 2015). Using this approach, it was possible to isolate and select the strains CPAC 7 (Bradyrhizobium diazoefficiens) and CPAC 15 (B. japonicum), included in the list of strains authorized for use as soybean commercial inoculants in 1992. These strains are currently used successfully by farmers in the Cerrado region. It is important to note that the annual economic return of BNF with soybeans in Brazil is estimated to be approximately US\$ 15 billion (Hungria and Mendes, 2015).

\section{CERRADO SOILS AS A SOURCE OF PHOSPHATE-SOLUBILIZING MICROBES}

Phosphorus limitation is another challenge to plant growth in Cerrado soils. The strategy of increasing P fertility with corrective fertilizer amendments is economically and environmentally limited due to the high amounts required and the low efficiency in response to the P-fixing capacity of these soils. To overcome these issues, microorganisms able to solubilize and mineralize P from inorganic and organic pools of total soil P have been used as inoculants to enhance plant $\mathrm{P}$ availability and acquisition. Oliveira et al. (2009) carried out a study to isolate and evaluate the phosphate solubilization activity of microorganisms associated with maize grown in Cerrado soil and select potential microbial inoculants. Bacillus sp. and Burkholderia sp. showed the greatest solubilization in media containing tricalcium phosphate, whereas the fungi Aspergillus terreus, Talaromyces rotundus, and Penicillium citrinum were the most effective in solubilizing P sources from aluminum, phytate, and lecithin, respectively. Abreu et al. (2017) reported for the first time the characterization of endophytic bacteria from maize growing in Cerrado lands and their potential to improve crop plant $\mathrm{P}$ acquisition in tropical soils. As a result of this work, the first Brazilian inoculant capable of increasing maize absorption of phosphorus was recently released (Embrapa, 2019). This product contains strains of Bacillus subtilis (isolated from maize leaf endosphere) and B. megaterium (isolated from maize rhizosphere), with the capacity to induce higher maize yield and grain P content under field conditions (de Sousa et al., 2020).

The high microbial diversity from Cerrado soils is expected to present a diverse number of features that could be explored biotechnologically. For example, Braga et al. (2018) isolated Bacillus spp. from the rice rhizosphere in the Cerrado, showing positive activity for catalase, protease, amylase, and nitrogenase; antibiosis against the phytopathogens Rhizoctonia solani and Sclerotinia sclerotiorum; phosphate solubilization; and improved rice plant growth under greenhouse conditions. Carrim et al. (2006) isolated bacteria from the leaves and stems of Jacaranda decurrens Cham (Bignoniaceae) and screened for some enzymes of biotechnological interest. The isolates of Bacillus spp., Pseudomonas spp., Corynebacterium spp., Actinomyces spp., and Staphylococcus spp. presented differential proteolytic, amylolytic, lipolytic, and esteratic activities. These studies show the vast potential of microorganisms associated with Cerrado plants for agricultural improvement and highlight the increasing expectations about the future use of these biological assets.

\section{CONCLUSION}

These results collectively show that assessing the plant-associated microbial diversity from semiarid regions could be an essential strategy to find PGPB that can successfully alleviate plant abiotic stress commonly present in such climates. Additionally, their plant growth promotion potential has become an interesting alternative to enhance crop yield using more sustainable 
agricultural practices. With society's eyes focusing on sustainable exploitation of natural resources and life quality improvement with environmentally friendly technologies, efforts to discover new PGPBs from harsh environments may sustain agricultural productivity in a future scenario of climate change and increased arid lands.

\section{AUTHOR CONTRIBUTIONS}

MB, GL-J, IM, and MQ contributed to the conception of this review. $\mathrm{MB}$ and $\mathrm{MQ}$ analyzed the plant-associated microbial diversity in semi-arid regions around the world. GL-J, FRJ, PF-J, and IM focused on the diversity of plant-assocated microbes from Brazilian semiarid and seasonally dry environments. MB and GL-J contributed equally to this work and have combined the first authorship. All authors contributed to manuscript revision and read and approved the submitted version.

\section{REFERENCES}

AbdElgawad, H., Saleh, A. M., Al Jaouni, S., Selim, S., Hassan, M. O., Wadaan, M. A., et al. (2019). Utilization of actinobacteria to enhance the production and quality of date palm (Phoenix dactylifera L.) fruits in a semi-arid environment. Sci. Total Environ. 665, 690-697. doi: 10.1016/j.scitotenv.2019. 02.140

Abreu, C. S., Figueiredo, J. E., Oliveira, C. A., dos Santos, V. L., Gomes, E. A., Ribeiro, V. P., et al. (2017). Maize endophytic bacteria as mineral phosphate solubilizers. Genet. Mol. Res. 16:gmr16019294. doi: 10.4238/gmr16019294

Adamoli, J., Macedo, J., Azevedo, L. G., and Madeira Netto, J. (1986). "Caracterização da região dos cerrados," in Solos Dos Cerrados: Tecnologia e Estratégias de Manejo, ed. W. J. Goedert (São Paulo, SP: EmbrapaCPAC/Nobel), 33-74.

Aidar, S., Chaves, A., Fernandes-Júnior, P. I., Oliveira, M., Neto, B., Calsa, T., et al. (2017). Vegetative desiccation tolerance of Tripogon spicatus (Poaceae) from the tropical semiarid region of northeastern Brazil. Funct. Plant Biol. 44, 1124-1133. doi: 10.1071/FP17066

Alvares, C. A., Stape, J. L., Sentelhas, P. C., de Moraes, G., Leonardo, J., and Sparovek, G. (2013). Köppen's climate classification map for Brazil. Meteorol. Z. 22, 711-728. doi: 10.1127/0941-2948/2013/0507

Andrade, W. L., Melo, A. S., Melo, Y. L., Sá, F. V. S., Rocha, M. M., Oliveira, A. P. S., et al. (2020). Bradyrhizobium inoculation plus foliar application of salicylic acid mitigates water deficit effects on cowpea. J. Plant Growth Regul. doi: 10.1007/s00344-020-10130-3

Antunes, G. R., Santana, S. R. A., Escobar, I. E. C., Brasil, M. de S., de Araujo, G. G. L., et al. (2019). Associative diazotrophic bacteria from forage grasses in the Brazilian semiarid region are effective plant growth promoters. Crop Pasture Sci. 70, 899-907. doi: 10.1071/CP19076

Araujo, J. F., de Castro, A. P., Costa, M. M., Togawa, R. C., Pappas, G. J., Quirino, B. F., et al. (2012). Characterization of soil bacterial assemblies in Brazilian savanna-like vegetation reveals acidobacteria dominance. Microb. Ecol. 64, 760-770. doi: 10.1007/s00248-012-0057-3

Arif, M. S., Riaz, M., Shahzad, S. M., Yasmeen, T., Akhtar, M. J., Riaz, M. A., et al. (2016). Associative interplay of plant growth promoting rhizobacteria (Pseudomonas aeruginosa QS40) with nitrogen fertilizers improves sunflower (Helianthus annuus L.) productivity and fertility of aridisol. Appl. Soil Ecol. 108, 238-247. doi: 10.1016/j.apsoil.2016.08.016

Armada, E., Probanza, A., Roldán, A., and Azcón, R. (2016). Native plant growth promoting bacteria Bacillus thuringiensis and mixed or individual mycorrhizal species improved drought tolerance and oxidative metabolism in Lavandula dentata plants. J. Plant Physiol. 192, 1-12. doi: 10.1016/j.jplph.2015. 11.007

\section{ACKNOWLEDGMENTS}

We thank the São Paulo Research Foundation for the financial support (grant process no. 2016/18944-3) and scholarship to GL-J (process no. 2017/24785-8). We thank Coordination for the Improvement of Higher Education Personnel for financially supporting MB (scholarship process no. 88882.317565/2019-01) and the Brazilian Council for Scientific and Technological Development for providing research productivity fellowships to PF-J (process no. 31128/2017-2) and MQ (process no. 311800/2019-0). We also thank the National Institute of Science and Technology "Plant Growth Promoting Microorganisms for Agricultural Sustainability and Environmental Responsibility" (National Institute of Science and Technology-MPCPAgro CNPq/Fundação Araucária STI/Coordination for the Improvement of Higher Education Personnel process no. 465133/2014-4) for providing financial support to PF-J and FRJ.

Baldani, J. I., Reis, V. M., Videira, S. S., Boddey, L. H., and Baldani, V. L. D. (2014). The art of isolating nitrogen-fixing bacteria from non-leguminous plants using N-free semi-solid media: a practical guide for microbiologists. Plant Soil 384, 413-431. doi: 10.1007/s11104-014-2186-2186

Bano, A., Batool, R., and Dazzo, F. (2010). Adaptation of chickpea to desiccation stress is enhanced by Symbiotic rhizobia. Symbiosis 50, 129-133. doi: 10.1007/ s13199-010-0051-59

Beck, H. E., Zimmermann, N. E., McVicar, T. R., Vergopolan, N., Berg, A., and Wood, E. F. (2018). Present and future Köppen-Geiger climate classification maps at 1-km resolution. Sci. Data 5:180214.

Berendsen, R. L., Pieterse, C. M. J., and Bakker, P. A. H. M. (2012). The rhizosphere microbiome and plant health. Trends Plant Sci. 17, 478-486. doi: 10.1016/J. TPLANTS.2012.04.001

Beuchle, R., Grecchi, R. C., Shimabukuro, Y. E., Seliger, R., Eva, H. D., Sano, E., et al. (2015). Land cover changes in the Brazilian Cerrado and Caatinga biomes from 1990 to 2010 based on a systematic remote sensing sampling approach. Appl. Geogr. 58, 116-127. doi: 10.1016/j.apgeog.2015. 01.017

Boddey, R. M., Peoples, M. B., Palmer, B., and Dart, P. J. (2000). Use of the ${ }^{15} \mathrm{~N}$ natural abundance technique to quantify biological nitrogen fixation by woody perennials. Nutr. Cycl. Agroecosyst. 57, 235-270. doi: 10.1023/A:1009890 514844

Bomfeti, C. A., Florentino, L. A., Guimarães, A. P., Cardoso, P. G., Guerreiro, M. C., and Moreira, F. M. de S. (2011). Exopolysaccharides produced by the symbiotic nitrogen-fixing bacteria of leguminosae. Rev. Bras. Ciên. Solo 35, 657-671. doi: 10.1590/s0100-06832011000 300001

Bontemps, C., Elliott, G. N., Simon, M. F., dos Reis Junior, F. B., Gross, E., Lawton, R. C., et al. (2010). Burkholderia species are ancient symbionts of legumes. Mol. Ecol. 19, 44-52. doi: 10.1111/j.1365-294X.2009.04458.x

Bournaud, C., de Faria, S. M., dos Santos, J. M. F., Tisseyre, P., Silva, M., Chaintreuil, C., et al. (2013). Burkholderia species are the most common and preferred nodulating symbionts of the Piptadenia group (Tribe Mimoseae). PLoS One 8:e63478. doi: 10.1371/journal.pone.0063478

Braga, L. F., Oliveira, F. A., Couto, E. A. P., Santos, K. F. D. N., Ferreira, E. P. B., and Martin-Didonet, C. C. G. (2018). Polyphasic characterization of bacteria obtained from upland rice cultivated in cerrado soil. Braz. J. Microbiol. 49, 20-28. doi: 10.1016/j.bjm.2017.04.004

Bustamante, M. M. C., Nardoto, G. B., and Martinelli, L. A. (2004). "Aspectos de ciclaje de nutrientes entre bosques amazónicos de terrafirme y sabanas tropicales (Cerrado brasileiro)," in Fisología Ecológica en Plantas: Mecanismos y Respuestas a Estrés en los Ecosistemas, ed. H. M. Cabrera (Valparaiso: Ediciones Universitarias de Valparaiso), 189-206. 
Carrim, A. J. I, Barbosa, E. C., and Vieira, J. D. G. (2006). Enzymatic activity of endophytic bacterial isolates of Jacaranda decurrens Cham. (Carobinhado-campo). Braz. Arch. Biol. Technol. 49, 353-359. doi: 10.1590/s151689132006000400001

Carvalho, M. H. C. (2008). Drought stress and reactive oxygen species. Plant Signal. Behav. 3, 156-165.

Castro, A. P., da Silva, M. R. S. S., Quirino, B. F., Bustamante, M. M. C., and Krüger, R. H. (2016). Microbial diversity in Cerrado biome (neotropical savanna) soils. PLoS One 11:e0148785. doi: 10.1371/journal.pone.0148785

Castro, A. P., Quirino, B. F., Pappas, G. Jr., Kurokawa, A. S., Neto, E. L., and Kruger, R. H. (2008). Diversity of soil fungal communities of Cerrado and its closely surrounding agriculture fields. Arch. Microbiol. 190, 129-139. doi: 10.1007/s00203-008-0374-376

Chauhan, A., Guleria, S., Balgir, P. P., Walia, A., Mahajan, R., Mehta, P., et al. (2017). Tricalcium phosphate solubilization and nitrogen fixation by newly isolated Aneurinibacillus aneurinilyticus CKMV1 from rhizosphere of Valeriana jatamansi and its growth promotional effect. Brazilian J. Microbiol. 48, 294-304. doi: 10.1016/j.bjm.2016.12.001

Chen, Y. P., Rekha, P. D., Arun, A. B., Shen, F. T., Lai, W. A., and Young, C. C. (2006). Phosphate solubilizing bacteria from subtropical soil and their tricalcium phosphate solubilizing abilities. Appl. Soil Ecol. 34, 33-41. doi: 10. 1016/j.apsoil.2005.12.002

da Silva, A. F., de Freitas, A. D. S., Costa, T. L., Fernandes, P. I., Martins, L. M. V. Santos, C. E. R. S., et al. (2017). Biological nitrogen fixation in tropical dry forests with different legume diversity and abundance. Nutr. Cycl. Agroecosyst. 107, 321-334. doi: 10.1007/s10705-017-9834-9831

da Silva, E. B. Jr., Fernandes Júnior, P. I., De Oliveira, P. J., Rumjanek, N. G., Boddey, R. M., and Xavier, G. R. (2012). Agronomic efficiency of a new rhizobial inoculant formulation for use in cowpea. Pesqui. Agropecu. Bras. 47, 138-141. doi: 10.1590/S0100-204X2012000100019

da Silva, J. F., da Silva, T. R., Escobar, I. E. C., Fraiz, A. C. R., dos Santos, J. W. M., do Nascimento, T. R., et al. (2018). Screening of plant growth promotion ability among bacteria isolated from field-grown sorghum under different managements in Brazilian drylands. World J. Microbiol. Biotechnol. 34:186. doi: 10.1007/s11274-018-2568-2567

Dall'Agnol, R. F., Plotegher, F., Souza, R. C., Mendes, I. C., dos Reis Junior, F. B., Bena, G., et al. (2016). Paraburkholderia nodosa is the main N2-fixing species trapped by promiscuous common bean (Phaseolus vulgaris L.) in the Brazilian 'Cerradão'. FEMS Microbiol. Ecol. 92:108. doi: 10.1093/femsec/ fiw 108

Damasco, G., Fontes, C., Françoso, R., and Haidar, R. (2018). The Cerrado biome: a forgotten biodiversity hotspot. Front. Young Minds 6:22. doi: 10.3389/frym. 2018.00022

de Albuquerque, U. P., de Lima Araújo, E., El-Deir, A. C. A., de Lima, A. L. A., Souto, A., Bezerra, B. M., et al. (2012). Caatinga revisited: ecology and conservation of an important seasonal dry forest. Sci. World J. 2012:205182. doi: $10.1100 / 2012 / 205182$

de Araujo, A. S. F., Bezerra, W. M., dos Santos, V. M., Nunes, L. A., de Lyra, M. D., Figueiredo, M. V. B., et al. (2017a). Fungal diversity in soils across a gradient of preserved Brazilian Cerrado. J. Microbiol. 55, 273-279. doi: 10.1007/s12275017-6350-6356

de Araujo, A. S. F., Bezerra, W. M., dos Santos, V. M., Rocha, S. M., Carvalho, N. D., de Lyra, M. D., et al. (2017b). Distinct bacterial communities across a gradient of vegetation from a preserved Brazilian Cerrado. Anton. Leeuw. 110, 457-469. doi: 10.1007/s10482-016-0815-811

de Freitas, A. D. S., Borges, W. L., Andrade, M. M. D. M., Sampaio, E. V. S. B., Santos, C. E. R. S., Passos, S. R., et al. (2014). Characteristics of nodule bacteria from Mimosa spp grown in soils of the Brazilian semiarid region. Afr. J. Microbiol. Res. 8, 788-796. doi: 10.5897/AJMR2013.6518

de Freitas, A. D. S., de Sá Barretto Sampaio, E. V., de Souza Ramos, A. P., de Vasconcellos Barbosa, M. R., Lyra, R. P., and Araújo, E. L. (2015). Nitrogen isotopic patterns in tropical forests along a rainfall gradient in Northeast Brazil. Plant Soil 391, 109-122. doi: 10.1007/s11104-015-2417-5

de Freitas, A. D. S., Sampaio, E. V. S. B., Santos, C. E. R. S., and Fernandes, A. R. (2010). Biological nitrogen fixation in tree legumes of the Brazilian semi-arid caatinga. J. Arid Environ. 74, 344-349. doi: 10.1016/j.jaridenv.2009. 09.018 de la Torre-Hernández, M. E., Salinas-Virgen, L. I., Aguirre-Garrido, J. F., Fernández-González, A. J., Martínez-Abarca, F., Montiel-Lugo, D., et al. (2020). Composition, structure, and PGPR traits of the rhizospheric bacterial communities associated with wild and cultivated echinocactus platyacanthus and neobuxbaumia polylopha. Front. Microbiol. 11:1424. doi: 10.3389/fmicb. 2020.01424

de Oliveira, I. S. R., Jesus, E. D. C., Ribeiro, T. G., da Silva, M. S. R. D. A., Tenorio, J. D. O., Martins, L. M. V., et al. (2019). Mimosa caesalpiniifolia Benth. adapts to rhizobia populations with differential taxonomy and symbiotic effectiveness outside of its location of origin. FEMS Microbiol. Ecol. 95:fiz109. doi: 10.1093/femsec/fiz109

de Sousa, S. M., de Oliveira, C. A., Andrade, D. L., de Carvalho, C. G., Ribeiro, V. P., Pastina, M. M., et al. (2020). Tropical Bacillus strains inoculation enhances maize root surface area, dry weight, nutrient uptake and grain yield. J. Plant Growth Regul. doi: 10.1007/s00344-020-10146-9

de Souza, L. Q., de Freitas, A. D. S., Sampaio, E. V. S. B., Moura, P. M., and Menezes, R. S. C. (2012). How much nitrogen is fixed by biological symbiosis in tropical dry forests? trees and shrubs. Nutr. Cycl. Agroecosyst. 94, 171-179. doi: 10.1007/s10705-012-9531-z

Dias, A., Pacheco, R. S., Santos, S. G. D., Xavier, G. R., Rumjanek, N. G., and Ribeiro, R. L. D. (2014). Screening of fluorescent rhizobacteria for the biocontrol of soilborne plant pathogenic fungi. Caatinga 27, 1-9.

dos Reis Junior, F. B., Simon, M. F., Gross, E., Boddey, R. M., Elliott, G. N., Neto, N. E., et al. (2010). Nodulation and nitrogen fixation by Mimosa spp. in the Cerrado and Caatinga biomes of Brazil. New Phytol. 186, 934-946.

dos Santos, J. M. F., Alves, P. A. C., Silva, V. C., Rhem, M. F. K., James, E. K., and Gross, E. (2017). Diverse genotypes of Bradyrhizobium nodulate herbaceous Chamaecrista (Moench) (Fabaceae, Caesalpinioideae) species in Brazil. Syst. Appl. Microbiol. 40, 69-79. doi: 10.1016/j.syapm.2016.12.004

Duca, D., Lorv, J., Patten, C. L., Rose, D., and Glick, B. R. (2014). Indole-3-acetic acid in plant-microbe interactions. Anton. Leeuw. 106, 85-125. doi: 10.1007/ s10482-013-0095-y

Egamberdieva, D., Kamilova, F., Validov, S., Gafurova, L., Kucharova, Z., and Lugtenberg, B. (2008). High incidence of plant growth-stimulating bacteria associated with the rhizosphere of wheat grown on salinated soil in Uzbekistan. Environ. Microbiol. 10, 1-9. doi: 10.1111/j.1462-2920.2007. 01424.x

El-Kahkahi, R., Moustaine, M., Channaoui, S., Hafidi, M., Zouhair, R., Chitt, M. A., et al. (2019). Characterization of plant growth promoting rhizobacteria isolated from the rhizosphere of carob tree (Ceratonia siliqua L.) in Morocco. Eurasian J. Biosci. 13, 921-930.

Elliott, G. N., Chen, W. M., Chou, J. H., Wang, H. C., Sheu, S. Y., Perin, L., et al. (2007). Burkholderia phymatum is a highly effective nitrogen-fixing symbiont of Mimosa spp. and fixes nitrogen ex planta. New Phytol. 173, 168-180. doi: 10.1111/j.1469-8137.2006.01894.x

Embrapa (2019). Product with Brazilian Technology can Reverse Dependence on Foreign Phosphorus Fertilizers. Available online at: https://www.embrapa.br/ en/busca-de-noticias/-/noticia/45773416/produto-com-tecnologia-brasileirapode-reverter-dependencia-externa-por-adubos-fosfatados (accessed December 12, 2019).

Fernandes-Júnior, P. I., Aidar, S. de T., Morgante, C. V., Gava, C. A. T., Zilli, J. É, Souza, L. S. B., et al. (2015). The resurrection plant Tripogon spicatus (Poaceae) harbors a diversity of plant growth promoting bacteria in northeastern Brazilian Caatinga. Rev. Bras. Ciênc. Solo 39, 993-1002. doi: 10. 1590/01000683rbcs20140646

Furley, P. A. (1999). The nature and diversity of neotropical savanna vegetation with particular reference to the Brazilian Cerrados. Glob. Ecol. Biogeogr. 8, 223-241. doi: 10.1046/j.1466-822X.1999.00142.x

Gaff, D. F. (1987). Desiccation tolerant plants in South America. Oecologia 74, 133-136. doi: 10.1007/BF00377357

Gao, J., Luo, Y., Wei, Y., Huang, Y., Zhang, H., He, W., et al. (2019). Screening of plant growth promoting bacteria (PGPB) from rhizosphere and bulk soil of Caragana microphylla in different habitats and their effects on the growth of Arabidopsis seedlings. Biotechnol. Biotech. Eq. 33, 921-930. doi: 10.1080/ 13102818.2019.1629841

Glick, B. R. (1995). The enhancement of plant growth by freemliving bacteria. Can. J. Microbial. 41, 109-117. doi: 10.1139/m95-015 
Glick, B. R. (2005). Modulation of plant ethylene levels by the bacterial enzyme ACC deaminase. FEMS Microbiol. Lett. 251, 1-7. doi: 10.1016/j.femsle.2005.07. 030

Glick, B. R., Penrose, D. M., and Li, J. (1998). A model for the lowering of plant ethylene concentrations by plant growth-promoting bacteria. J. Theor. Biol. 190, 63-68. doi: 10.1006/jtbi.1997.0532

Grover, M., Ali, S. Z., Sandhya, V., Rasul, A., and Venkateswarlu, B. (2011). Role of microorganisms in adaptation of agriculture crops to abiotic stresses. World J. Microbiol. Biotechnol. 27, 1231-1240. doi: 10.1007/s11274-010-0572-577

Hasanuzzaman, M., Nahar, K., Gill, S. S., and Fujita, M. (2013). "Drought stress responses in plants, oxidative stress, and antioxidant defense," in Climate Change and Plant Abiotic Stress Tolerance, eds N. Tuteja and S. S. Gill (Weinheim: John Wiley \& Sons), 209-250. doi: 10.1002/9783527675265.ch09

Hungria, M., and Mendes, I. C. (2015). "Nitrogen fixation with soybean: the perfect symbiosis?”, in Biological Nitrogen Fixation, ed. F. J. de Bruijn (New Jersey: Wiley-Blackwell), 1005-1019.

Hungria, M., Campo, R. J., Souza, E. M., and Pedrosa, F. O. (2010). Inoculation with selected strains of Azospirillum brasilense and a. lipoferum improves yields of maize and wheat in Brazil. Plant Soil 331, 413-425. doi: 10.1007/s11104-0090262-0

Ibekwe, A. M., Ors, S., Ferreira, J. F. S., Liu, X., and Suarez, D. L. (2017). Seasonal induced changes in spinach rhizosphere microbial community structure with varying salinity and drought. Sci. Total Environ. 579, 1485-1495. doi: 10.1016/ j.scitotenv.2016.11.151

Idris, E. E., Iglesias, D. J., Talon, M., and Borriss, R. (2007). Tryptophan-dependent production of indole-3-acetic acid (IAA) affects level of plant growth promotion by Bacillus amyloliquefaciens FZB42. Mol. Plant Microbe Interact. 20, 619-626. doi: 10.1094/MPMI-20-6-0619

Jochum, M., McWilliams, K. M., Borrego, E., Kolomiets, M., Niu, G., Pierson, E., et al. (2019). Bioprospecting plant growth-promoting rhizobacteria that mitigate drought stress in grasses. Front. Microbiol. 10:2106. doi: 10.3389/fmicb. 2019.02106

Kavamura, V. N., Santos, S. N., Silva, J. L. D., Parma, M. M., Ávila, L. A., Visconti, A., et al. (2013a). Screening of Brazilian cacti rhizobacteria for plant growth promotion under drought. Microbiol. Res. 168, 183-191. doi: 10.1016/j.micres. 2012.12.002

Kavamura, V. N., Taketani, R. G., Lançoni, M. D., Andreote, F. D., Mendes, R., Soares, et al. (2013b). Water regime influences bulk soil and rhizosphere of Cereus jamacaru bacterial communities in the Brazilian Caatinga Biome. PLoS One 8:e73606. doi: 10.1371/journal.pone.0073606

Klink, C. A., and Solbrig, O. T. (1996). "Efeito do fogo na biodiversidade de plantas do cerrado," in Biodiversidad y Funcionamento de Pastizales y Sabanas en América Latina, eds G. Sarmiento and M. Gabido (Mérida: Cyted y Cielat), 231-244.

Kukreja, S., Nandwal, A. S., Kumar, N., Sharma, S. K., Unvi, V., and Sharma, P. K. (2005). Plant water status, $\mathrm{H}_{2} \mathrm{O}_{2}$ scavenging enzymes, ethylene evolution and membrane integrity of Cicer arietinum roots as affected by salinity. Biol. Plant. 49, 305-308. doi: 10.1007/s10535-005-5308-4

Kumar, V., Kayasth, M., Chaudhary, V., and Gera, R. (2014). Diversity of diazotrophs in arid and semi-arid regions of Haryana and evaluation of their plant growth promoting potential on Bt-cotton and pearl millet. Ann. Microbiol. 64, 1301-1313. doi: 10.1007/s13213-013-0774-y

Lacerda-Júnior, G. V., Noronha, M. F., Cabral, L., Delforno, T. P., De Sousa, S. T. P., Fernandes-Júnior, P. I., et al. (2019). Land use and seasonal effects on the soil microbiome of a Brazilian dry forest. Front. Microbiol. 10:648. doi: $10.3389 /$ fmicb. 2019.00648

Lewis, G. P., Schrire, B., MacKinder, B., and Lock, M. (2005). Legumes of the World. Kew: Royal Botanic Gardens. 577.

Li, J., Ovakim, D., Charles, T., et al. (2000). An ACC deaminase minus mutant of Enterobacter cloacae UW4No longer promotes root elongation. Curr. Microbiol. 41, 101-105. doi: 10.1007/s002840010101

Liang, T., Yang, G., Ma, Y., Yao, Q., Ma, Y., Ma, H., et al. (2019). Seasonal dynamics of microbial diversity in the rhizosphere of Ulmus pumila L. var. sabulosa in a steppe desert area of Northern China. PeerJ 7:e7526. doi: 10.7717/peerj.7526

Liu, H., Brettell, L. E., Qiu, Z., and Singh, B. K. (2020). Microbiome-mediated stress resistance in plants. Trends Plant Sci. 25, 733-743. doi: 10.1016/j.tplants.2020. 03.014
Machado, P. L. O. A., and Silva, C. A. (2001). Soil management under notillage systems in the tropics with special reference to Brazil. Nutr. Cycl. Agroecosyst. 61, 119-130. doi: 10.1023/A:1013331805519

Malhotra, M., and Srivastava, S. (2008). An ipdC gene knock-out of Azospirillum brasilense strain SM and its implications on indole-3-acetic acid biosynthesis and plant growth promotion. Anton. van Leeuwenhoek 93, 425-433. doi: 10. 1007/s10482-007-9207-x

Marasco, R., Rolli, E., Vigani, G., Borin, S., Sorlini, C., Ouzari, H., et al. (2013). Are drought-resistance promoting bacteria cross-compatible with different plant models? Plant Signal. Behav. 8:e26741. doi: 10.4161/psb.26741

Marinho, R. de C. N., Nóbrega, R. S. A., Zilli, J. E., Xavier, G. R., Santos, C. A. F., Aidar, S. de T., et al. (2014). Field performance of new cowpea cultivars inoculated with efficient nitrogen-fixing rhizobial strains in the Brazilian Semiarid. Pesqui. Agropecu. Bras. 49, 395-402. doi: 10.1590/S0100204X2014000500009

Marris, E. (2005). The forgotten ecosystem. Nature 437, 944-945. doi: 10.1038/ $437944 a$

Martins, L. M. V., Xavier, G. R., Rangel, F. W., Ribeiro, J. R. A., Neves, M. C. P., Morgado, L. B., et al. (2003). Contribution of biological nitrogen fixation to cowpea: a strategy for improving grain yield in the semi-arid region of Brazil. Biol. Fertil. Soils 38, 333-339. doi: 10.1007/s00374-003-06 68-664

Martins, P. G. S., Lira Junior, M. A., Fracetto, G. G. M., da Silva, M. L. R. B., Vincentin, R. P., and de Lyra, M. C. C. P. (2015). Mimosa caesalpiniifolia rhizobial isolates from different origins of the Brazilian Northeast. Arch. Microbiol. 197, 459-469. doi: 10.1007/s00203-014-1078-1078

Martiny, J. B. H., Bohannan, B. J. M., Brown, J. H., Colwell, R. K., Fuhrman, J. A., Green, J. L., et al. (2006). Microbial biogeography: putting microorganisms on the map. Nat. Rev. Microbiol. 4, 102-112. doi: 10.1038/nrmicro1341

Mendes, I. C., Fernandes, M. F., Chaer, G. M., and dos Reis Junior, F. B. (2012). Biological functioning of Brazilian Cerrado soils under different vegetation types. Plant Soil. 359, 183-195. doi: 10.1007/s11104-012-1195-1196

Mendes, R., Kruijt, M., de Bruijn, I., Dekkers, E., van der Voort, M., Schneider, J. H. M., et al. (2011). Deciphering the rhizosphere microbiome for disease-suppressive bacteria. Science 332, 1097-1100. doi: 10.1126/science.12 03980

Menezes, K. A. S., Escobar, I. E. C., Fraiz, A. C. R., Martins, L. M. V., and FernandesJúnior, P. I. (2017). Genetic variability and symbiotic efficiency of Erythrina velutina Willd. root nodule bacteria from the semi-arid region in Northeastern Brazil. Rev. Bras. Ciênc. Solo 41:e0160302. doi: 10.1590/18069657rbcs20 160302

Menezes, K. A. S., Nunes, G. F. D. O., Sampaio, A. A., de Souza, L. S. B., Gava, C. A. T., Martins, L. M. V., et al. (2016). Diversity of new root nodule bacteria from Erythrina velutina willd., a native legume from the Caatinga dry forest (Northeastern Brazil). Rev. Ciênc. Agrárias 39, 222-233. doi: 10.19084/ RCA15050

Mercante, F. M., Otsubo, A. A., and Brito, O. R. (2017). New native rhizobia strains for inoculation of common bean in the Brazilian savanna. Rev. Bras. Ciênc. Solo 41, 120-150. doi: 10.1590/18069657rbcs20150120

Minaxi, L. N., and Saxena, J. (2010). Disease suppression and crop improvement in moong beans (Vigna radiata) through Pseudomonas and Burkholderia strains isolated from semi arid region of Rajasthan. India. BioControl. 55, 799-810. doi: 10.1007/s10526-010-9292-z

Minaxi, L. N., Yadav, R. C., and Saxena, J. (2012). Characterization of multifaceted Bacillus sp. RM-2 for its use as plant growth promoting bioinoculant for crops grown in semi arid deserts. Appl. Soil Ecol. 59, 124-135. doi: 10.1016/j.apsoil. 2011.08.001

Mishra, B. K., Meena, K. K., Dubey, P. N., Aishwath, O. P., Kant, K., Sorty, A. M., et al. (2016). Influence on yield and quality of fennel (Foeniculum vulgare Mill.) grown under semi-arid saline soil, due to application of native phosphate solubilizing rhizobacteria isolated. Ecol. Eng. 97, 327-333. doi: 10. 1016/j.ecoleng.2016.10.034

Misra, S., Dixit, V. K., Khan, M. H., Mishra, S. K., Dviwedi, G., Yadav, S., et al. (2017). Exploitation of agro-climatic environment for selection of 1-aminocyclopropane-1-carboxylic acid (ACC) deaminase producing salt tolerant indigenous plant growth promoting rhizobacteria. Microbiol. Res. 205, 25-34. doi: 10.1016/j.micres.2017.08.007 
Myers, N., Mittermeier, R. A., Mittermeier, C. G., da Fonseca, G. A. B., and Kent, J. (2000). Biodiversity hotspots for conservation priorities. Nature 403, 853-858. doi: $10.1038 / 35002501$

Naseem, H., Ahsan, M., Shahid, M. A., and Khan, N. (2018). Exopolysacchardes producing rhizobacteria and their role in plant growth and drought tolerance. J. Basic Microbiol. 58, 1009-1022. doi: 10.1002/jobm.201800309

Naylor, D., and Coleman-Derr, D. (2018). Drought stress and root-associated bacterial communities. Front. Plant Sci. 8:2223. doi: 10.3389/fpls.2017.02223

Ngumbi, E., and Kloepper, J. (2016). Bacterial-mediated drought tolerance: current and future prospects. Appl. Soil Ecol. 105, 109-125. doi: 10.1016/j.apsoil.2016. 04.009

Niu, X., Song, L., Xiao, Y., and Ge, W. (2018). Drought-tolerant plant growth-promoting rhizobacteria associated with foxtail millet in a semi-arid agroecosystem and their potential in alleviating drought stress. Front. Microbiol. 8:2580. doi: 10.3389/fmicb.2017.02580

Oliveira, C. A., Alves, V. M. C., and Marriel, I. E. (2009). Phosphate solubilizing microorganisms isolated from rhizosphere of maize cultivated in an oxisol of the Brazilian Cerrado Biome. Soil Biol. Biochem. 41, 1782-1787. doi: 10.1016/j. soilbio.2008.01.012

Paul, D., and Lade, H. (2014). Plant-growth-promoting rhizobacteria to improve crop growth in saline soils: a review. Agron. Sustain. Dev. 34, 737-752. doi: 10.1007/s13593-0140-0233-236

Peix, A., Ramírez-Bahena, M. H., Velázquez, E., and Bedmar, E. J. (2015). Bacterial associations with legumes. CRC. Crit. Rev. Plant Sci. 34, 17-42. doi: 10.1080/ 07352689.2014.897899

Pires, R. C., dos Reis Junior, F. B., Zilli, J. E., Fischer, D., Hofmann, A., James, E. K., et al. (2018). Soil characteristics determine the rhizobia in association with different species of Mimosa in central Brazil. Plant Soil 423, 411-428. doi: 10.1007/s11104-017-3521-3525

Quecine, M. C., Araújo, W. L., Rossetto, P. B., Ferreira, A., Tsui, S., Lacava, P. T., et al. (2012). Sugarcane growth promotion by the endophytic bacterium Pantoea agglomerans 33.1. Appl. Environ. Microbiol. 78, 7511-7518. doi: 10. 1128/AEM.00836-812

Queiroz, L. P., Cardoso, D., Fernandes, M. F., and Moro, M. F. (2017). “Diversity and evolution of flowering plants of the caatinga domain," in Caatinga, eds J. M. C. Silvia, I. R. Leal, and M. Tabarelli (Cham: Springer International Publishing), 23-63. doi: 10.1007/978-3-319-68339-3_2

Quirino, B. F., Pappas, G. J., Tagliaferro, A. C., Collevatti, R. G., Neto, E. L., da Silva, M. R. S., et al. (2009). Molecular phylogenetic diversity of bacteria associated with soil of the savanna-like Cerrado vegetation. Microbiol. Res. 164, 59-70. doi: 10.1016/j.micres.2006. 12.001

Ratter, J. A., Ribeiro, J. F., and Bridgewater, S. (1997). The Brazilian cerrado vegetation and threats to its biodiversity. Ann. Bot. 80, 223-230. doi: 10.1006/ anbo.1997.0469

Ribeiro, J. F., and Walter, B. M. T. (1998). “Fitofisionomias do bioma Cerrado," in Cerrado: Ambiente e Flora, eds S. M. Sano and S. P. Almeida (Planaltina, DF: Embrapa-CPAC), 87-166.

Ribeiro, J. F., and Walter, B. M. T. (2008). "As principais fitofisionomias do bioma Cerrado," in Cerrado: ecologia e flora, v. 2, eds S. M. Sano, S. P. Almeida, and J. F. Ribeiro (Brasília, DF: Embrapa-CPAC), 153-212.

Ribeiro, J. F., Sano, S. M., Macêdo, J., and Silva, J. A. (1983). Os Principais Tipos Fitofisionômicos da Região dos Cerrados. Planaltina, DF: Embrapa-CPAC, 28.

Ribeiro, R. A., Rogel, M. A., López-López, A., Ormeño-Orrillo, E., Barcellos, F. G., Martínez, J., et al. (2012). Reclassification of Rhizobium tropici type a strains as Rhizobium leucaenae sp. nov. Int. J. Syst. Evol. Microbiol. 62, 1179-1184. doi: 10.1111/j.1469-8137.2010.03267.x

Rodrigues, D. R., Silva, A. F., Cavalcanti, M. I. P., Escobar, I. E. C., Fraiz, A. C. R., Ribeiro, P. R. A., et al. (2018). Phenotypic, genetic and symbiotic characterization of Erythrina velutina rhizobia from Caatinga dry forest. Braz. J. Microbiol. 49, 503-512. doi: 10.1016/j.bjm.2017. 09.007

Ruggiero, P. G. C., Batalha, M. A., Pivello, V. R., and Meirelles, S. T. (2002). Soil-vegetation relationships in cerrado (Brazilian savanna) and semideciduous forest. Southeastern Brazil. Plant Ecol. 160, 1-16. doi: 10.1023/A.101581 921386

Salgado, E. V., Andrade, E. M. D., Hevia, J. N., Nunes, E. P., and Rodrigues, M. M. D. A. (2015). Rainfall patterns and the contribution of litter in the caatinga dry tropical forest. Rev. Ciên. Agron. 46, 299-309. doi: 10.5935/18066690.20150009

Sandhya, V. S. K. Z., Ali, S. Z., Grover, M., Reddy, G., and Venkateswarlu, B. (2010). Effect of plant growth promoting Pseudomonas spp. on compatible solutes, antioxidant status and plant growth of maize under drought stress. Plant Growth Regul. 62, 21-30. doi: 10.1007/s10725-10-94 79-9474

Santana, S. R. A., Voltolini, T. V., Antunes, G. D. R., da Silva, V. M., Simões, W. L., Morgante, C. V., et al. (2020). Inoculation of plant growth-promoting bacteria attenuates the negative effects of drought on sorghum. Arch. Microbiol. 202, 1015-1024. doi: 10.1007/s00203-020-01810-1815

Santos, A. F. J., Morais, J. S. D., Miranda, J. S., Moreira, Z. P. M., Feitoza, A. F. A., Leite, J., et al. (2020). Cacti-associated rhizobacteria from Brazilian Caatinga biome induce maize growth promotion and alleviate abiotic stress. Rev. Bras. Ciências Agrárias 15:e8221. doi: 10.5039/agraria.v15 i3a 8221

Selim, S., Hassan, Y. M., Saleh, A. M., Habeeb, T. H., and AbdElgawad, H. (2019). Actinobacterium isolated from a semi-arid environment improves the drought tolerance in maize (Zea mays L.). Plant Physiol. Bioch. 142, 15-21. doi: 10.1007/ s00442-004-1520-1528

Shrivastava, P., and Kumar, R. (2015). Soil salinity: a serious environmental issue and plant growth promoting bacteria as one of the tools for its alleviation. Saudi J. Biol. Sci. 22, 123-131. doi: 10.1016/j.sjbs.2014.12.001

Silva, J. L. S. E., Cruz-Neto, O., Peres, C. A., Tabarelli, M., and Lopes, A. V. (2019). Climate change will reduce suitable Caatinga dry forest habitat for endemic plants with disproportionate impacts on specialized reproductive strategies. PLoS One 14:e0217028. doi: 10.1371/journal.pone. 0217028

Singh, R. P., and Jha, P. N. (2017). The PGPR Stenotrophomonas maltophilia SBP9 augments resistance against biotic and abiotic stress in wheat plants. Front. Microbiol. 8:1945. doi: 10.3389/fmicb.2017.01945

Sorty, A. M., Meena, K. K., Choudhary, K., Bitla, U. M., Minhas, P. S., and Krishnani, K. K. (2016). Effect of plant growth promoting bacteria associated with halophytic weed (Psoralea corylifolia L) on germination and seedling growth of wheat under saline conditions. Appl. Bioch. Biotech. 180, 872-882. doi: $10.1007 /$ s12010-016-2139-z

Souza, R. C., Mendes, I. C., dos Reis Junior, F. B., Carvalho, F. M., Nogueira, M. A., Vasconcelos, A. T. R., et al. (2016). Shifts in taxonomic and functional microbial diversity with agriculture: how fragile is the Brazilian Cerrado? BMC Microbiol. 16:42. doi: 10.1186/s12866-016-0657-z

Strassburg, B. B. N., Brooks, T., Feltran-Barbieri, R., Iribarrem, A., Crouzeilles, R., Loyola, R., et al. (2017). Moment of truth for the Cerrado hotspot. Nat. Ecol. Evol. 1:99. doi: 10.1038/s41559-017-0099

Taketani, R. G., Kavamura, V. N., Mendes, R., and Melo, I. S. (2014). Functional congruence of rhizosphere microbial communities associated to leguminous tree from Brazilian semiarid region. Environ. Microbiol. Rep. 7, 95-101. doi: 10.1111/1758-2229.12187

Taketani, R. G., Lançoni, M. D., Kavamura, V. N., Durrer, A., Andreote, F. D., and Melo, I. S. (2017). Dry season constrains bacterial phylogenetic diversity in a semi-arid rhizosphere system. Microb. Ecol. 73, 153-161. doi: 10.1007/s00248016-0835-834

Teixeira, F. C. P., Borges, W. L., Xavier, G. R., and Rumjanek, N. G. (2010). Characterization of indigenous rhizobia from Caatinga. Braz. J. Microbiol. 41, 201-208. doi: 10.1590/S1517-83822010000100029

Teixeira, F. C. P., Reinert, F., Rumjanek, N. G., and Boddey, R. M. (2006). Quantification of the contribution of biological nitrogen fixation to Cratylia mollis using the ${ }^{15} \mathrm{~N}$ natural abundance technique in the semi-arid Caatinga region of Brazil. Soil Biol. Biochem. 38, 1989-1993. doi: 10.1016/j.soilbio.2005. 11.013

Tuba, Z., and Lichtenthaler, H. K. (2011). "Ecophysiology of homoiochlorophyllous and poikilochlorophyllous desiccation-tolerant plants and vegetations," in Plant Desiccation Tolerance, Ecological Studies (Analysis and Synthesis), eds U. Lüttge, E. Beck, and D. Bartels (Berlin: Springer), 157-183. doi: 10.1007/978-3-642-19106-0_9

Wang, E. T. (2019). Symbiosis between Rhizobia and Legumes. In: Ecology and Evolution of Rhizobia. Singapore: Springer.

Wang, S., Ouyang, L., Ju, X., Zhang, L., Zhang, Q., and Li, Y. (2014). Survey of plant drought-resistance promoting bacteria from Populus euphratica tree 
living in arid area. Indian J. Microbiol. 54, 419-426. doi: 10.1007/s12088-014-04 79-473

Williams, A., and de Vries, F. T. (2020). Plant root exudation under drought: implications for ecosystem functioning. New Phytol. 225, 1899-1905. doi: 10. 1111/nph.16223

Yasmin, H., Bano, A., and Ullah, S. (2013). Screening of PGPR isolates from semiarid region and their implication to alleviate drought stress. Pak. J. Bot. 45, 51-58.

Zappi, D. C., Filardi, F. L. R., Leitman, P., Souza, V. C., Walter, B. M. T., Pirani, J. R., et al. (2015). Growing knowledge: an overview of seed plant diversity in Brazil. Rodriguésia 66, 1085-1113. doi: 10.1590/2175-7860201566411
Conflict of Interest: The authors declare that the research was conducted in the absence of any commercial or financial relationships that could be construed as a potential conflict of interest.

Copyright (c) 2021 Bonatelli, Lacerda-Júnior, dos Reis Junior, Fernandes-Júnior, Melo and Quecine. This is an open-access article distributed under the terms of the Creative Commons Attribution License (CC BY). The use, distribution or reproduction in other forums is permitted, provided the original author(s) and the copyright owner(s) are credited and that the original publication in this journal is cited, in accordance with accepted academic practice. No use, distribution or reproduction is permitted which does not comply with these terms. 